2. To: (Receiving Organization)

\section{Distribution}

5. Proj./Prog./Dept./Div.:

Spent Nuclear Fuel Project

8. Originator Remarks: Engr.

D. J. Trimble
REACTION RATE EQUATIONS FROM LITERATURE REVIEW DATA

3. From: (Originating Organization) SNF Characterization Project

6. Design Authority/ Design Agent/Cog.

11. Receiver Remarks: 11A. Design Baseline Document? [] Yes [X] No
NA

. Equip./Component No.: NA

10. System/Bldg./Facility:

NA

4. Related EDT NO.:

7. Purchase Order No.:

12. Major Assm. Dwg. No.: NA

13. Permit/Permit Application No.: NA

14. Required Response Date:

NA

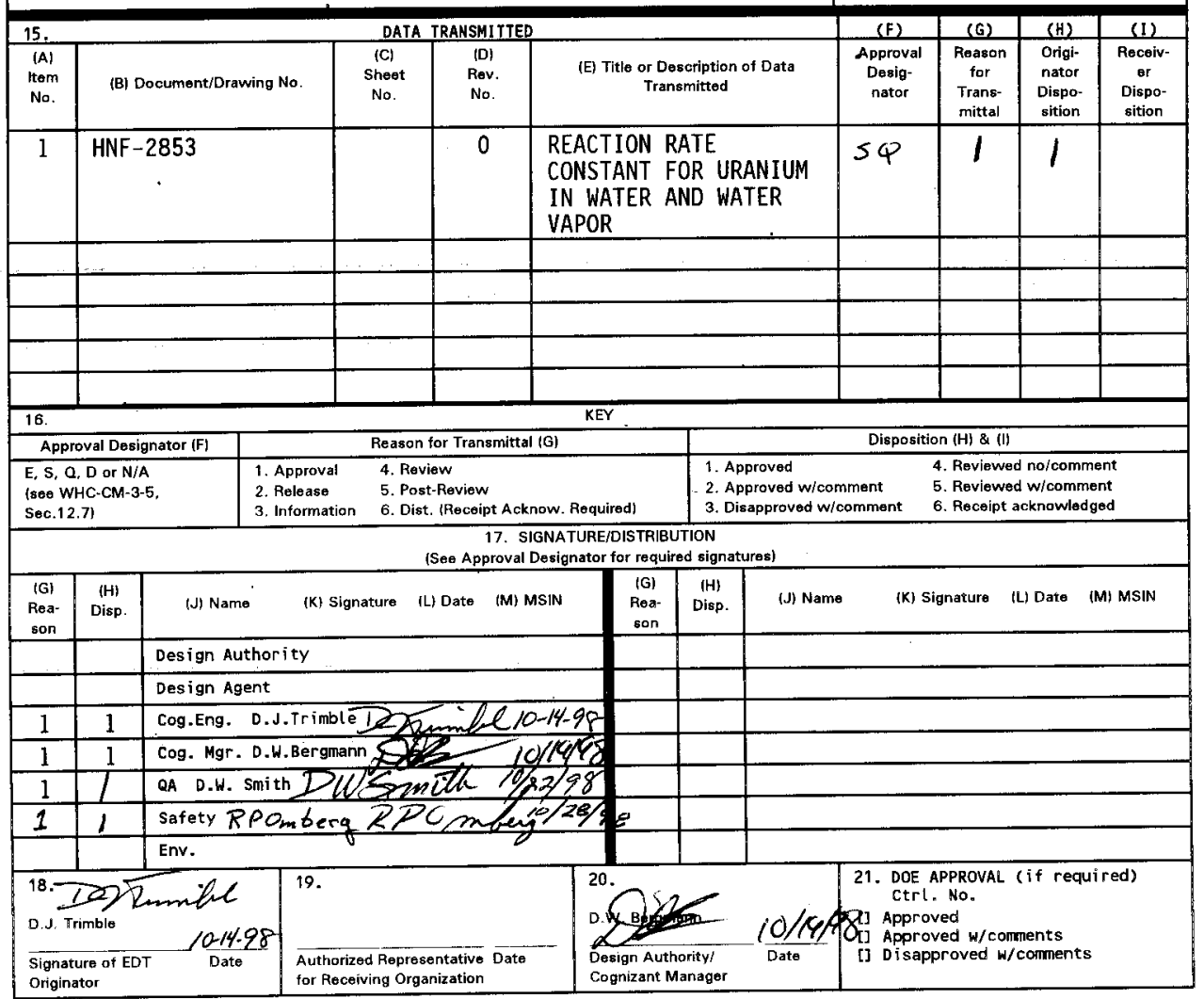




\title{
REACTION RATE CONSTANT FOR URANIUM IN WATER AND WATER VAPOR
}

\author{
D. J. Trimble
}

Duke Engineering \& Services Hanford, Inc, Richland, WA 99352

U.S. Department of Energy Contract DE-AC06-96RL13200

EDT/ECN: $620819 \quad$ UC: 2070

Org Code: $2 F 700$

Charge Code: 105357 EHOO HN 960131

B\&R Code: EW7040000

Total Pages: 45 쓰.

Key Words: Oxidation Rate, Uranium, K Basin

Abstract: The literature on uranium oxidation in water and oxygen free water vapor was reviewed. Arrhenius rate equations were developed from the review data. These data and equations will be used as a baseline from which to compare reaction rates measured for $\mathrm{K}$ Bas in fuel.

TRADEMARK DISCLAIMER. Reference herein to any specific comercial product, process, or service by trade name, trademark, manufacturer, or otherwise, does not necessarily constitute or imply its endorsement, recommendation, or favoring by the United States Government or any agency thereof or its contractors or subcontractors.

Printed in the United States of America. Jo obtain copies of this document, contact: Document Control Services, P.O. Box 950, Mailstop H6-08, Richland WA 99352, Phone (509) 372-2420; Fax (509) 376-4989.

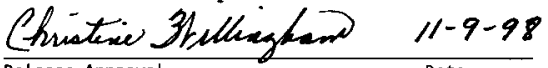
Rel ease Approval Date

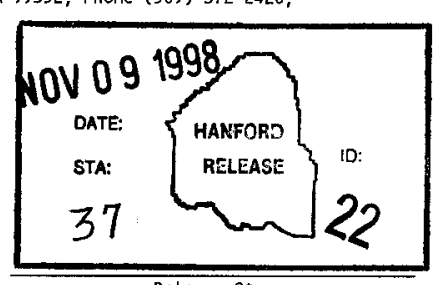

Release stamp 
HNF-2853, Rev. 0

\section{CONTENTS}

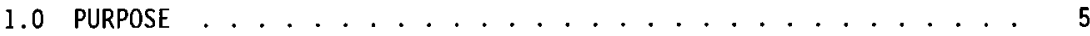

2.0 SUMMARY . . . . . . . . . . . . . . . . . . . . . . . 5

2.1 IN OXYGEN FREE WATER VAPOR ............. 6

2.2 IN LIQUID WATER . . . . . . . . . . . . . . . 6

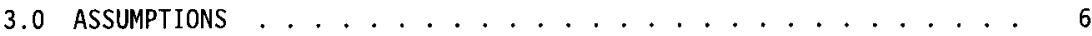

4.0 SOURCES OF INFORMATION ................... 7

5.0 REACTION RATES . . . . . . . . . . . . . . 7

5.1 DEFINITION OF TERMS . . . . . . . . . . . . 7

5.2 OXIDATION OF URANIUM IN WATER AND OXYGEN FREE WATER VAPOR . . 9

5.3 WATER VAPOR DATA AND ANALYSIS .............. 9

5.3.1 Vapor Pressure Dependence . . . . . . . . . . . . 9

5.3.2 Temperature Dependence . . . . . . . . . . . . 14

5.3.3 Irradiation and Water Storage Effects . . . . . . . 16

5.4 WATER IMMERSION DATA AND ANALYSIS ........... 17

5.5 COMPARISON WITH LITERATURE EQUATIONS ........... 19

6.0 CONCLUSIONS ................................... 19

7.0 REFERENCES .......................... 21

APPENDIX A DATA BASE FOR OXIDATION OF URANIUM IN WATER

AND OXYGEN FREE WATER VAPOR .......... 25 
HNF-2853, Rev. 0

\section{LIST OF FIGURES}

1. Literature 0xidation Rate Data for Uranium in Oxygen Free Water Vapor . . . . . . . . . . . . . . . . . . 10

2. Effect of Water Vapor Pressure on Oxidation of Uranium in Oxygen Free Water Vapor at (a) $40{ }^{\circ} \mathrm{C}$ to $150{ }^{\circ} \mathrm{C}$ and (b) at $300{ }^{\circ} \mathrm{C}$ to $600{ }^{\circ} \mathrm{C} \ldots \ldots . . \ldots 13$

3. Reaction Rate Data for Uranium in Oxygen Free Water Vapor . . . 15

4. Effect of Low Irradiation ( $<0.1$ MWD/MTU) on Oxidation of Uranium in 0xygen Free Water Vapor ....... . . . . . 16

5. Oxidation of Uranium in (a) Liquid Water and (b) Saturated Water Vapor .................. . 18

6. Comparison of Literature Equations Used in the Technical Databook, Literature Review Data, and the Line Fit to the Review Data . . . . . . . . . . . . . . 20

\section{LIST OF TABLES}

1. Results from Linear Regressions of Literature Data for Oxidation of Uranium in Oxygen Free Water Vapor ........ 12 
HNF-2853, Rev. 0

This page intentionally left blank. 
HNF-2853, Rev. 0

\section{REACTION RATE CONSTANT FOR URANIUM IN WATER AND WATER VAPOR}

\subsection{PURPOSE}

The purpose of this work is to review the literature on oxidation of uranium metal in water and oxygen free water vapor and to develop equations for reaction rate constant using the available data. The data and equations are compared to the equations in the Project Technical Databook (Reilly 1998).

The Technical Databook equations provide input parameters for calculation of the chemical reaction of $K$ Basin fuel in Mult $i-C a n i s t e r$ Overpacks (MCOs). These equations are from the literature and were developed from the data of a few investigators (Cooper 1997). When reaction rate data for $K$ Basin fuel becomes available they will be compared to the Technical Databook equations and to the literature review data. If sufficient differences are seen revised equations will be developed for the Technical Databook as was done for the dry air oxidation equations (Trimble 1998).

\subsection{SUMMARY}

The reaction rate constant is defined in the following general equation.

$$
R=A_{s} \times F_{a} \times k
$$

where:

$$
R=\text { Reaction rate }
$$

$A_{s}=$ Geometric fuel surface area

$F_{a}=$ Enhancement factor to account for the following: (1) true reacting surface sometimes called a roughness factor, (2) uranium metal inclusions including hydrides from water exposure, and (3) other effects such as irradiation

$k$ = Temperature and vapor pressure dependent reaction rate, typically an Arrhenius form.

The following equations were derived from literature data and define the reaction rate constant $(k)$ for unirradiated uranium where $k$ is weight gain in $\mathrm{mg} / \mathrm{cm}^{2}-h$, $T$ is temperature in degrees Kelvin (K) and $P$ is water vapor pressure in $\mathrm{kPa}$. Since the data was for unirradiated material containing little or no hydride, in contrast to the irradiated $K$ Basin fuel that contains substantial hydride, the equations may not represent oxidation of $K$ Basin fuel. 
HNF-2853, Rev. 0

\subsection{IN OXYGEN FREE WATER VAPOR}

At $T \leq 568 \mathrm{~K}$,

$\log k=4.947-2375 / T+0.5 * \log (P)$ for $P \leq 101 \mathrm{kPa}$

and

$\log k=3.945-2375 / \mathrm{T}+1 * \log (\mathrm{P})$ for $\mathrm{P}>101 \mathrm{kPa}$.

At $568<\mathrm{T} \leq 852 \mathrm{~K}$,

$\log k=0.7655+0.5 * \log (P)$ for $P \leq 101 \mathrm{kPa}$

and

$\log k=-0.2366+1 * \log (P)$ for $P>101 \mathrm{kPa}$

At $T>852 \mathrm{~K}$,

$\log k=3.454-2290 / T+0.5 * \log (P)$ for $P \leq 101 \mathrm{kPa}$

and

$\log k=2.452-2290 / T+1 * \log (P)$ for $P>101 \mathrm{kPa}$

\subsection{IN LIQUID WATER}

$\log k=8.956-3516 / T$ for $T \leq 573 K$

\subsection{ASSUMPTIONS} equation:

Linear oxidation is assumed for all conditions according to the following

$$
W=k \times t
$$

where:

$W$ is weight gain per unit surface area, $t$ is time, and $k$ is the rate constant.

It is assumed that the initial oxidation of clean, unoxidized uranium surfaces exposed to water and oxygen free inert gas occurs in a linear manner. Linear oxidation is also assumed for oxidized surfaces that have developed from exposure to the oxidizing atmosphere as well as from long term water storage. 0xidation at all stages will therefore be 1 inear and progress according to Equation (3.1), and the rate constant at a given temperature and vapor pressure will be the same for unoxidized as well as oxidized surfaces. 


\subsection{SOURCES OF INFORMATION}

Data for oxidation of unirradiated uranium in oxygen free water vapor were extracted from the literature and are listed in Appendix A. Ritchie (1981) and Pearce (1989) reviewed current reaction rate data for uranium in various environments including oxygen free water vapor and provided rate law equations. Ritchie (1981) lists data from several sources (Besson and Santon 1963; Corcoran et al., 1965; Magnani 1974; Grimes and Morris 1965; Jackson and Condon 1977; Kondo et al., 1974; Kondo et a1., 1964; Orman 1963, 1964; Waber 1958). Ritchie (1981) also provides data from previously unpublished sources (Baker et al., 1981; Orman 1962; Orman and Walker 1964). Pearce (1989) plots many of the data in Ritchie (1981) as well as data from additional sources (Baker 1964; Colmenares 1984; Hopkinson 1959; Huddle 1953; Pearce and Kay 1987; Ritchie 1984; Ritchie 1986; Scott 1959; Wathen 1943; Weirick 1984). In addition data were also extracted from other sources (Hayward 1994; Lemmon 1957; Troutner 1960).

Oxidation rate data for uranium in liquid water are listed in Appendix A. Reviews by Waber (1952) and McWhirter and Draley (1952) provided data by Benson et al. (1945), Draley and English (1945), Colbeck et al. (1945), Greninger et a1. (1945), and Mollison et a1. (1945). Other data were obtained from Baker et a1. (1966), Orman (1963), Schroeder (1959), Troutner (1960), and Waber (1958).

\subsection{REACTION RATES}

The issue is the number of corrosion events that occur in a given time at a given temperature. This is the product of the reactive fuel surface area and the corresponding rate constant. In actual practice it may not be necessary to know each of these two parameters if measurements of reaction products such as hydrogen are conducted. However, for modeling calculations specific values for each of these parameters are necessary. The Project Technical Databook (Reilly 1998) provides fuel surface area values and reaction rate equations for applicable environments for use in design and safety evaluations. The reaction rate equations presented here are consistent with the terms defined and used in the Databook.

\subsection{DEFINITION OF TERMS}

The primary interest in estimating oxidation rates of $\mathrm{K}$ Basin fuel in an MCO originates with the need to define the rate of potential chemical reactions. These reactions are exothermic and can result in the net production of gaseous products. Therefore, the reaction rates become important factors for predicting thermal transients in an $M C O$ and the potential for over pressurization.

The reaction of uranium metal fuel in an MCO with a number of different reactants will occur as an MCO is loaded at the basins, transferred, dried, staged, conditioned, and stored. The reactants of interest can vary with the 
type of analysis under consideration (e.g., prediction of routine processing, analys is of accident conditions, etc.), however, the main reactants of interest include water, oxygen, and hydrogen. The general form of the relationship used to predict reaction rates is as follows.

$$
R=A_{s} \times F_{a} \times k
$$

where:

$R=$ Uranium reaction rate, $m g$ of weight gain/hour

$A_{s}=$ Geometric surface area of uranium exposed to reactants, $\mathrm{cm}^{2}$

$F_{a}=$ Reactivity factor, to account for the true reacting surface sometimes called a roughness factor, dimension less

$k=$ Reaction rate constant, $\mathrm{mg}$ of weight gain $/ \mathrm{h}-\mathrm{cm}^{2}$

These terms are defined in more detail as follows.

Reaction Rate (R)--The reaction rate describes the mass of oxygen reacted per unit of time.

Geometric Surface Area $\left(A_{s}\right)^{--T h e}$ area of uranium exposed to reactants estimated by geometric dimensions assuming a smooth surface.

Reactivity Factor $F_{a}$--This enhancement factor accounts for the following: (1) the true reacting surface which can conceptually be thought of as the roughness of the actual uranium metal surface, increasing the smooth surface area associated with the geometric dimensions, (2) alloy inclusions including hydride, and (3) characteristics of the native oxide present on the reacting surface.

Reaction Rate Constant $(k)$--The reaction rate constant is an exponential function of water vapor pressure and inverse absolute temperature (Arrhenius relationship).

Reaction rate data are typically generated in the laboratory under controlled conditions and, for solid/gas or solid/liquid reactions, reported as a function of reactant concentration, temperature, and surface area. Placing the reaction rate data on a unit surface area basis allows use of the laboratory data for a variety of different configurations that may be encountered in practice. Specimens used to obtain laboratory data have some undefined degree of surface roughness which is ignored in this document. Laboratory observations typically focus on determining the reaction rate dependence on temperature and reactant concentration. 
HNF-2853, Rev. 0

\subsection{OXIDATION OF URANIUM IN WATER AND OXYGEN FREE WATER VAPOR}

The reaction of uranium with water and water vapor is

$$
\mathrm{U}+(2+\mathrm{X}) \mathrm{H}_{2} \mathrm{O} \rightarrow \mathrm{UO}_{2+\mathrm{X}}+(2+\mathrm{X}) \mathrm{H}_{2}
$$

with $\mathrm{x}<0.25$ at temperatures up to about $250{ }^{\circ} \mathrm{C}$ (Colmenares 1984 ; Baker et al., 1966; Pearce 1989). There is some evidence that $\mathrm{U}_{3} \mathrm{O}_{8}$ becomes increasingly important at temperatures in excess of roughly $300{ }^{\circ} \mathrm{C}$. other species such as hydroxides, hydrated oxides and $\mathrm{UH}_{3}$ are probably also involved at various temperatures. The release of non-stoichiometric hydrogen has been observed indicating the formation of uranium hydride as an intermediate in a sequence of reactions

$$
\begin{aligned}
& \mathrm{U}+2 \mathrm{H}_{2} \mathrm{O}-\cdots>\mathrm{UO}_{2}+2 \mathrm{H}_{2} \\
& \mathrm{U}+3 / 2 \mathrm{H}_{2}-\rightarrow \mathrm{UH}_{3}
\end{aligned}
$$

(Baker et al., 1966).

The reaction kinetics are generally observed to be essentially linear below about $800{ }^{\circ} \mathrm{C}$ (Colmenares 1984; Pearce 1989; Ritchie 1981). Above $800{ }^{\circ} \mathrm{C}$ rates that decrease with time have been usually observed during initial testing (Pearce 1989). The linear rates that are reported and used in this work were either final rates after about one to two hours of exposure or were the average rates at the end of the test assuming linear kinetics.

\subsection{WATER VAPOR DATA AND ANALYSIS}

The data base for oxidation in oxygen free water vapor is a collection of Tinear rate data for unirradiated uranium from a number of authors. These data are tabulated in Appendix $A$.

\subsubsection{Vapor Pressure Dependence}

The dependence of reaction rate constant $(k)$ on water vapor pressure (P) has been studied by several investigators (Colmenares, 1984; Ritchie, 1983, 1986; Pearce and Kay, 1987). The dependency is generally agreed to be approximately equal to the square root of the pressure such that at constant temperature

$$
\frac{k_{1}}{k_{2}}=\left(\frac{P_{1}}{P_{2}}\right)^{0.5}
$$

Assuming this dependency holds over a large range of temperature the 7 iterature data were normalized for pressure by dividing the rate by $p^{0.5}$ and are shown on an Arrhenius plot (Figure 1). This plot shows data breaks at two temperatures (about $300^{\circ} \mathrm{C}$ and $600{ }^{\circ} \mathrm{C}$ ), and three groups of data appear 
Figure 1. Literature Oxidation Rate Data for Uranium in 0xygen Free Water Vapor. (Data is normalized to $1 \mathrm{kPa}$ water vapor pressure.)

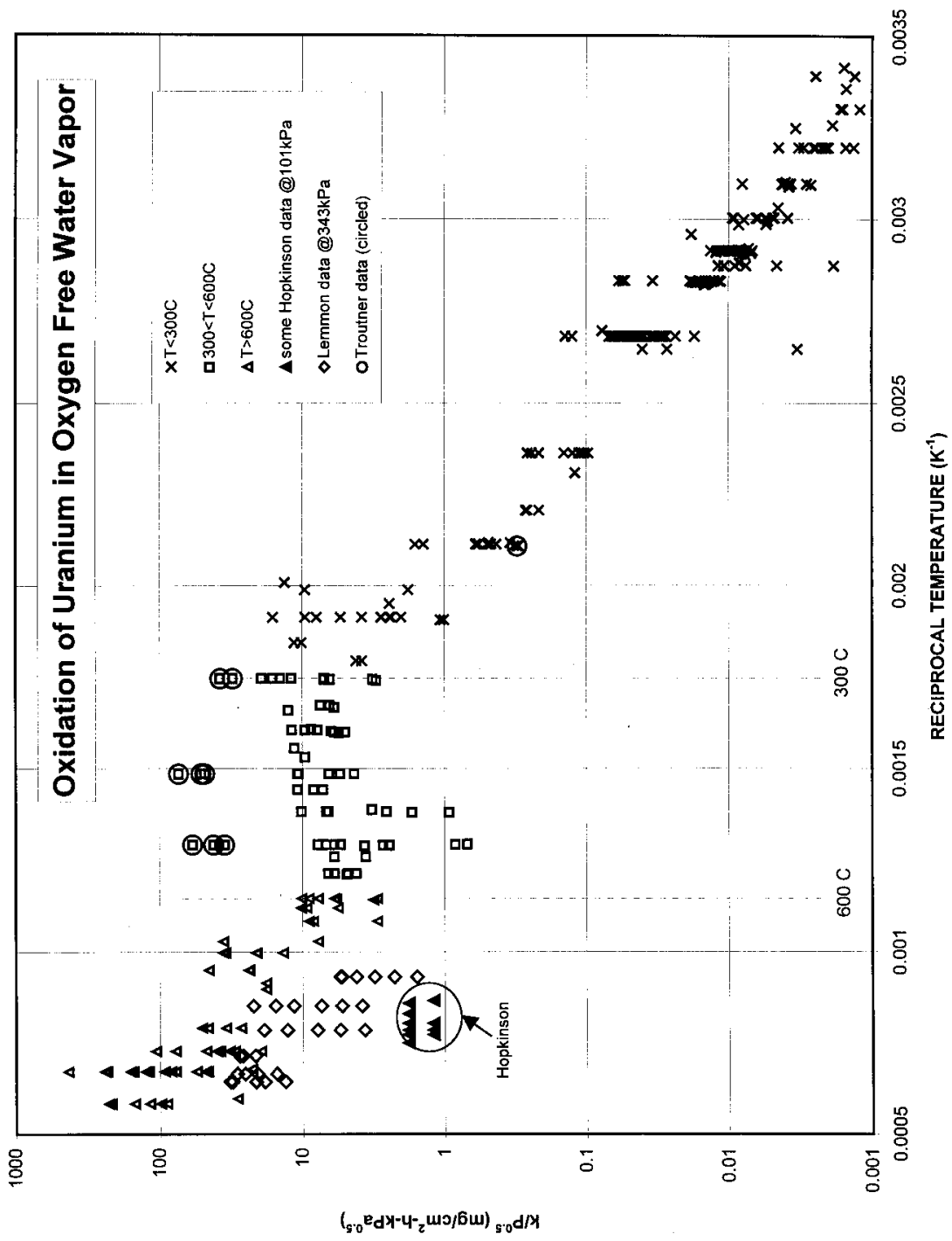


exceptional when compared to the remaining data within the bounds of the temperature breaks. At $300{ }^{\circ} \mathrm{C}$ to $600{ }^{\circ} \mathrm{C}$ the data at pressure greater than $101 \mathrm{kPa}$ (Troutner 1960) lie significantly above the data in this range. Above $600{ }^{\circ} \mathrm{C}$ a subset of data by Hopkinson (1959) lie below the remaining data and the data at $343 \mathrm{kPa}$ (Lemmon 1957) are in the lower region of the data, excluding the noted Hopkinson data.

Multiple linear regression analyses were performed for the data in each of the three temperature regions. Inverse temperature $\left(K^{-1}\right)$ and $10 \mathrm{~g}$ (pressure, $\mathrm{kPa}$ ) were the independent variables and $\log \left(\right.$ rate, $\mathrm{mg} / \mathrm{cm}^{2}-\mathrm{h}$ ) was the dependent variable in the analyses of the temperature-pressure model

$\log (k)=a+b / T+n * \log (P)$

The results of these regressions are given in Table 1 .

The regression results for the data at $\mathrm{T}<300{ }^{\circ} \mathrm{C}$ gave a pressure dependence coefficient of $0.469 \pm 0.046$ which is in good agreement with the 1iterature value of 0.5 . The pressure in this temperature range varied from less than $0.01 \mathrm{kPa}$ to $101 \mathrm{kPa}$ plus one datum at $1377 \mathrm{kPa}$. When the regression was performed excluding the $1377 \mathrm{kPa}$ datum, the results were essentially unchanged.

Pressure dependence was also evaluated at constant temperatures of $40{ }^{\circ} \mathrm{C}$, $70{ }^{\circ} \mathrm{C}, 100{ }^{\circ} \mathrm{C}$ and $150{ }^{\circ} \mathrm{C}$. A plot of these data and the 1 inear regressions of $\log k$ versus $\log P$ are shown on Figure $2 a$. The pressure dependency coefficient, $n$, ranged from 0.44 to 0.81 . The 0.81 value was from the data set $\left(40^{\circ} \mathrm{C}\right)$ having the least pressure range $(1.2 \mathrm{kPa}$ to $7.3 \mathrm{kPa})$ and having the lowest correlation coefficient $\left(R^{2}\right)$. The regression statistics on the $40{ }^{\circ} \mathrm{C}$ data allow for a possible value of $n=0.5$.

The data in the temperature range $300{ }^{\circ} \mathrm{C}$ to $600{ }^{\circ} \mathrm{C}$ includes vapor pressures at primarily $101 \mathrm{kPa}$ pressure with a few points in the range of $1377 \mathrm{kPa}$ to $13770 \mathrm{kPa}$. Regression analysis gave a coefficient of 1.00 for pressure dependence and a smal1, positive and not highly significant coefficient for reciprocal temperature $(1 / T)$ dependence. When no temperature dependence $(b=0)$ was assumed regression analysis again yielded a pressure dependency coefficient of $1.00(0.997 \pm 0.13)$ with an $R^{2}$ of 0.79 (Figure $2 b$ ). The line for $n=0.5$, also on Figure $2 b$, falls well below the high pressure data but approaches the datum for $P<100 \mathrm{kPa}$. Insufficient data was available to determine pressure dependence at pressure less than $101 \mathrm{kPa}$. An assumption of $n=0.5$ at $P<101 \mathrm{kPa}$ provides higher rate values than $n=1$ and would, therefore, be conservative and is consistent with the lower temperature results.

At temperature greater than $600{ }^{\circ} \mathrm{C}$ the data includes two pressures: $101 \mathrm{kPa}$ and $344 \mathrm{kPa}$. Regression analys is of these data indicates a negative pressure dependence with no statistical significance. The $344 \mathrm{kPa}$ data (Lemmon 1957) were obtained from hydrogen evolution data and were converted to weight gain data assuming stoichiometric generation of hydrogen. Thus, there may be some uncertainty regarding these data. The literature gives no guidance here, so the following conservative assumptions were used to be consistent with the other temperature ranges: at $P \leq 101 \mathrm{kPa}, \mathrm{n}=0.5$, and at $\mathrm{P}>101 \mathrm{kPa}, \mathrm{n}=1.0$. 
HNF-2853, Rev. 0

Table 1. Results from Linear Regressions of Literature Data for Oxidation of Uranium in 0xygen Free Water Vapor.

\begin{tabular}{|c|c|c|c|c|c|c|c|c|c|c|}
\hline \multirow[b]{3}{*}{$\begin{array}{l}\text { Temperature } \\
\text { Range }\left({ }^{\circ} \mathrm{C}\right)\end{array}$} & \multirow[b]{3}{*}{$\mathrm{N}$} & \multirow[b]{3}{*}{$R^{2}$} & \multirow[b]{3}{*}{$\begin{array}{c}\text { std } \\
\text { error }\end{array}$} & \multirow{2}{*}{\multicolumn{2}{|c|}{$\frac{\text { Intercept }}{\mathrm{a}}$}} & \multicolumn{4}{|c|}{$X$ Coefficients } & \multirow[b]{3}{*}{ Comment } \\
\hline & & & & & & \multicolumn{2}{|r|}{ b } & \multicolumn{2}{|r|}{$n$} & \\
\hline & & & & Value & $\begin{array}{l}2 \times \text { std } \\
\text { error }\end{array}$ & Value & $\begin{array}{l}2 \times \text { std } \\
\text { error }\end{array}$ & Value & $\begin{array}{l}2 \times \text { std } \\
\text { error }\end{array}$ & \\
\hline$T<299$ & 242 & 0.958 & 0.238 & 5.110 & 0.290 & -2423 & 96.1 & 0.469 & 0.046 & \\
\hline $299<\mathrm{T}<599$ & 62 & 0.817 & 0.278 & -1.232 & 0.658 & 699 & 396.5 & 1.00 & 0.123 & \\
\hline $299<T<599$ & 62 & 0.789 & 0.301 & -0.227 & 0.152 & 0 & NA & 1.00 & 0.133 & $\begin{array}{l}\text { Assumes no } \\
\text { temperature } \\
\text { dependence }\end{array}$ \\
\hline$T>599$ & 100 & 0.341 & 0.492 & 4.766 & 1.080 & -2197 & 603.1 & -0.30 & 0.408 & $\begin{array}{l}\text { All data } \\
\text { including } \\
\text { Lemmon and } \\
\text { Hopkinson }\end{array}$ \\
\hline$T>599$ & 100 & 0.340 & 0.495 & 4.073 & 0.499 & -2130 & 599.4 & 0 & NA & $\begin{array}{l}\text { A11 data, } \\
\text { no pressure } \\
\text { dependence }\end{array}$ \\
\hline$T>599$ & 90 & 0.607 & 0.310 & 4.260 & 0.315 & -2200 & 377.0 & 0 & NA & $\begin{array}{l}\text { No pressure } \\
\text { dependence, } \\
\text { w/o } \\
\text { Hopkinson } \\
10 \text { data }\end{array}$ \\
\hline$T>599$ & 60 & 0.736 & 0.270 & 4.456 & 0.306 & -2290 & 356.2 & 0 & NA & $\begin{array}{l}\text { No pressure } \\
\text { dependence, } \\
\text { w/o } \\
\text { Hopkinson } \\
10 \text { data or } \\
\text { Lemmon data }\end{array}$ \\
\hline
\end{tabular}

'Regressions used the model $\log k=a+b / T+n \log P$ where $\mathrm{T}=$ Temperature $(\mathrm{K})$ $\mathrm{P}=$ Vapor Pressure $(\mathrm{kPa})$.

${ }^{2}$ Standard error on the regression.

${ }^{3}$ Two times the standard error on the parameter.

$N A=$ Not applicable. 
HNF-2853, Rev. 0

Figure 2. Effect of Water Vapor Pressure on Oxidation of Uranium in Oxygen Free Water Vapor at (a) $40{ }^{\circ} \mathrm{C}$ to $150{ }^{\circ} \mathrm{C}$ and (b) at $300{ }^{\circ} \mathrm{C}$ to $600{ }^{\circ} \mathrm{C}$.
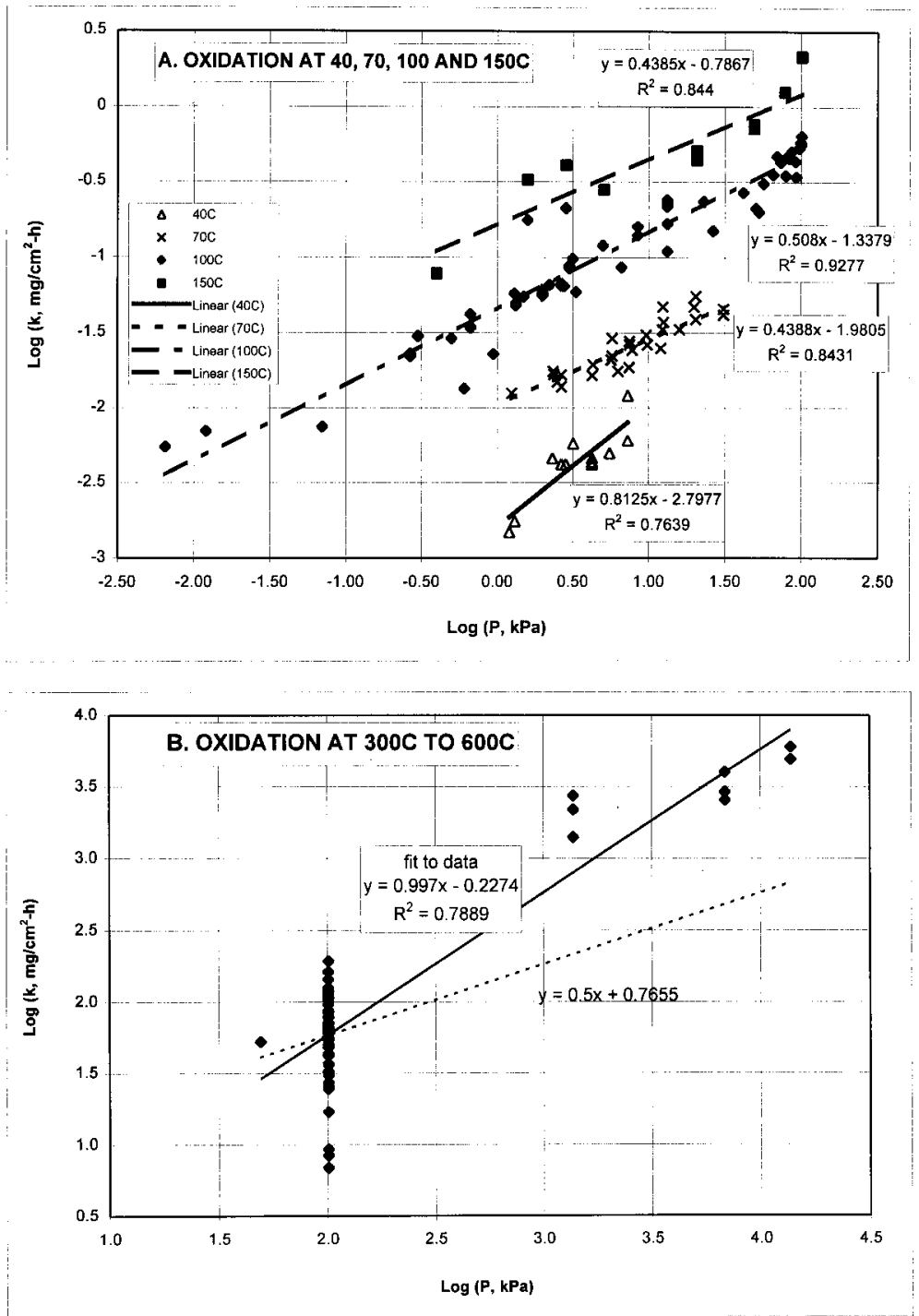
A plot of the data (Figure 3) normalized to 1 atmosphere (101 kPa) vapor pressure using pressure dependency assumptions of $n=0.5$ at $P \leq 101 \mathrm{kPa}$ and $\mathrm{n}=1.0$ at $\mathrm{P}>101 \mathrm{kPa}$ shows consistency of the data within the following the three temperature regimes: $\mathrm{T}<295{ }^{\circ} \mathrm{C}, 295{ }^{\circ} \mathrm{C}<\mathrm{T}<579{ }^{\circ} \mathrm{C}$ and $\mathrm{T}>579{ }^{\circ} \mathrm{C}$. Figure 3 includes the data by Troutner (1960), but it does not include the data by Lemmon (1957) nor the offending subset of data by Hopkinson (1959).

\subsubsection{Temperature Dependence}

Using the pressure dependency assumptions discussed above, coefficients for temperature dependence were derived from regression analysis of the reaction rate $(\mathrm{k})$ data normalized to a pressure of 1 atmosphere $(101 \mathrm{kPa})$ and using the model

$$
\log k^{\prime}=a+b / T
$$

where $k^{\prime}=k(101 / P)^{n}$, $k$ is weight gain in $\mathrm{mg} / \mathrm{cm}^{2}-h$, $T$ is temperature in degrees Kelvin $(K), P$ is water vapor pressure in $k P a, n=0.5$ at $P \leq 101 \mathrm{kPa}$ and $n=1.0$ at $P>101 \mathrm{kPa}$ (Figure 3 ). The regressions were performed in each of the three temperature regimes indicated in Figure 3 . The temperature limits for each equation were determined by the intercepts of the regression 1ines.

$$
\begin{aligned}
& \text { At } T \leq 568 K\left(295^{\circ} \mathrm{C}\right) \\
& \quad \log k=5.949-n * \log (101)-2375 / T+n * \log P
\end{aligned}
$$

thus for $P \leq 101 \mathrm{kPa}$

$$
\log k=4.947-2375 / T+0.5 * \log P
$$

and for $P>101 \mathrm{kPa}$

$$
\log k=3.945-2375 / T+1.0 * \log P
$$

$$
\text { At } \mathrm{T}>852 \mathrm{~K}\left(579^{\circ} \mathrm{C}\right)
$$

$$
\log k=4.456-n * \log (101)-2290 / T+n * \log P
$$

thus for $P \leq 101 \mathrm{kPa}$

$$
\log k=3.454-2290 / T+0.5 * \log P
$$

and for $\mathrm{P}>101 \mathrm{kPa}$

$$
\log k=2.452-2290 / T+1.0 * \log P
$$

In the range $568 \mathrm{~K}<\mathrm{T} \leq 852 \mathrm{~K}$ the rate constant data indicated no significant temperature dependence (as discussed in Section 5.4.1), and the average for $\log k$ ' was used to derive the following equation:

$$
\log k=1.7677-n * \log (101)+n * \log P
$$




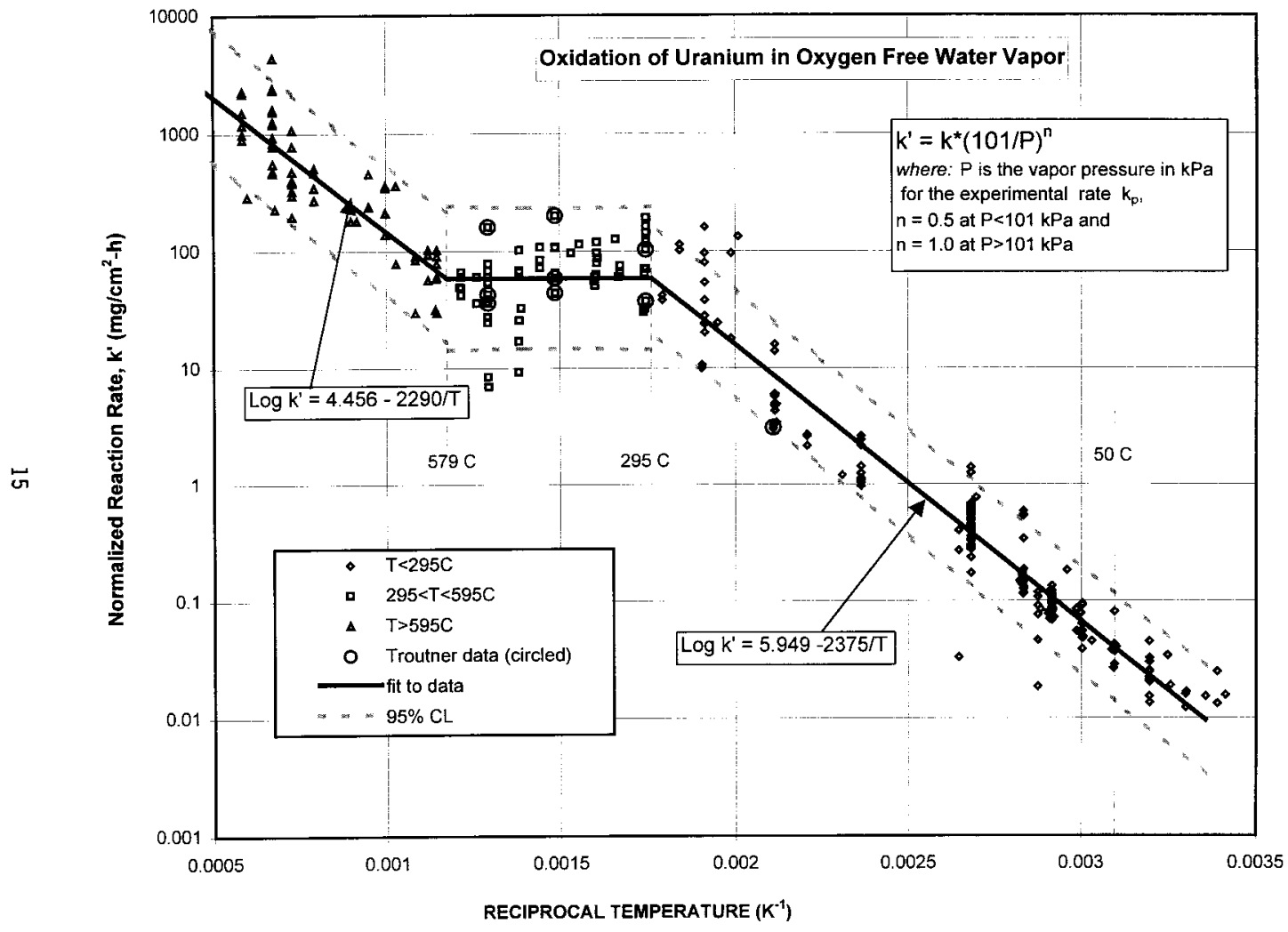

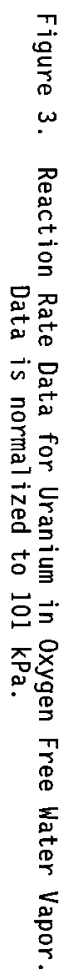


for $P \leq 101 \mathrm{kPa}$

$$
\log k=0.7655+0.5 * \log P
$$

and for $\mathrm{P}>101 \mathrm{kPa}$

$$
\log k=-0.2366+1.0 * \log P
$$

The 1 ines for the above equation are shown on Figure 3 with the $95 \%$ confidence interval lines.

\subsubsection{Irradiation and Water Storage Effects}

A limited amount of oxidation data for irradiated uranium oxidized in oxygen free water vapor was available (Scott 1959). These data, listed in Appendix $A$ and plotted in Figures 1 and 3 , are for high temperature $\left(730^{\circ} \mathrm{C}\right.$ to $1215^{\circ} \mathrm{C}$ ) and low irradiation $\left(10^{14}\right.$ nvt, less than 0.1 MWD/MTU). No effect of this level of irradiation on oxidation rate was measured (Figure 4). The irradiation exposure of the $\mathrm{N}$ Reactor fuel stored in the $\mathrm{K}$ Basins averages about 2500 MWD/MTU and ranges up to 5000 MWD/MTU. While tests in dry air did not indicate an effect of the $N$ Reactor irradiation (Abrefah et al. 1998), testing of the $K$ Basin fuel in water vapor would be prudent.

Figure 4. Effect of Low Irradiation (<0.1 MWD/MTU) on 0xidation of Uranium in 0xygen Free Water Vapor.

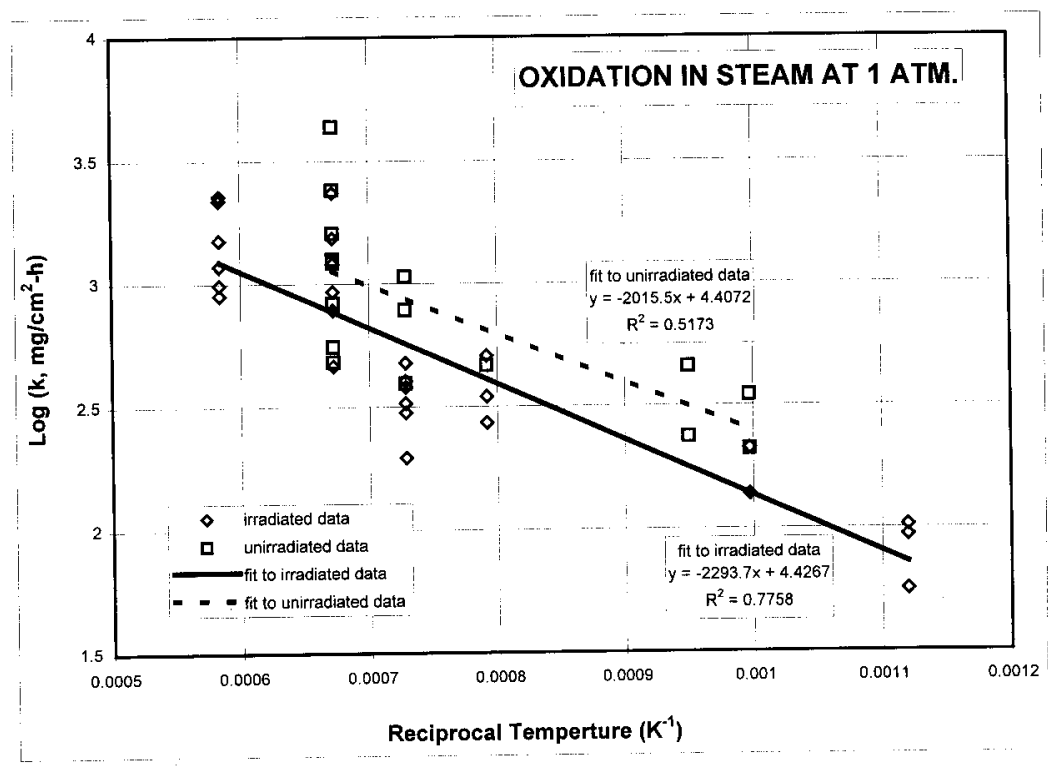


Water storage of exposed metallic fuel corrodes the uranium and can create uranium hydride particulate in the fuel matrix at and near the exposed surfaces. Such inclusions have been observed in $\mathrm{K}$ Basin fue $\mathrm{T}$ (Marschman, Pyecha, and Abrefah 1997). It has been proposed that these hydrides contributed to the measured increase in dry air reaction rate of the $\mathrm{K}$ Basin fuel compared to the literature data for unirradiated uranium (Abrefah et al. 1998).

Only one known data point exists for uranium hydride in water or water vapor, and it indicates that the rate of oxidation is less than for uranium metal (Baker et al. 1966). This however, is inadequate for making conclusions on the effect of hydride particulate on the reaction rate of $K$ Basin fuel. Measurements are planned for $K$ Basin fuel in oxygen free water vapor. When these data become available the Technical Databook (Reilly 1998) rate law equations and/or enhancement factors will be reevaluated.

\subsection{WATER IMMERSION DATA AND ANALYSIS}

0xidation rate data for uranium in deaerated water at temperature up to $300{ }^{\circ} \mathrm{C}$ was found in several literature sources. They are 1 isted in Appendix $A$ and plotted on Figure $5 a$. The linear regression fit to the water immersion data is

$$
\log k=8.956-3516 / T
$$

Data by Waber (1958) do not fit with the remaining data and were not used in this correlation. Corrosion rates of uranium in water are inhibited by dissoived oxygen (Orman, 1963; Waber, 1952). This is illustrated (Figure 5a) by rate data for air saturated water. Hydrogen saturated water data indicate no effect relative to oxygen free water and were used with gas free, helium saturated, and nitrogen saturated water data to derive Equation (5.11).

Water vapor data at saturation pressures and the lines for Equations (5.4) and (5.5) at saturated water vapor are shown on Figure $5 b$. Data at $225^{\circ} \mathrm{C}$ and $300{ }^{\circ} \mathrm{C}$ were adjusted to the saturation pressure according to the ratio of the saturation pressure, and the test pressure. Below $100{ }^{\circ} \mathrm{C}$ the water immersion data line falls on the line for saturated water vapor. Above $100{ }^{\circ} \mathrm{C}$ and one atmosphere vapor pressure the pressure dependency for water vapor increases and the slope of the saturated water vapor line increases.

Water corrosion rates for $K$ Basin fuel were derived from hydrogen generation data collected from shipping container storage of the fuel in preparation for shipment to the 300 Area hot cells (Pajunen 1998). These data, plotted on Figure 5a, are in good agreement with the 1 iterature data.

The present Databook equation for liquid water is in good agreement with the equations of this document for water and water vapor (Figure $5 b$ ). 
Figure 5. Oxidation of Uranium in (a) Liquid Water and (b) Saturated Water Vapor.
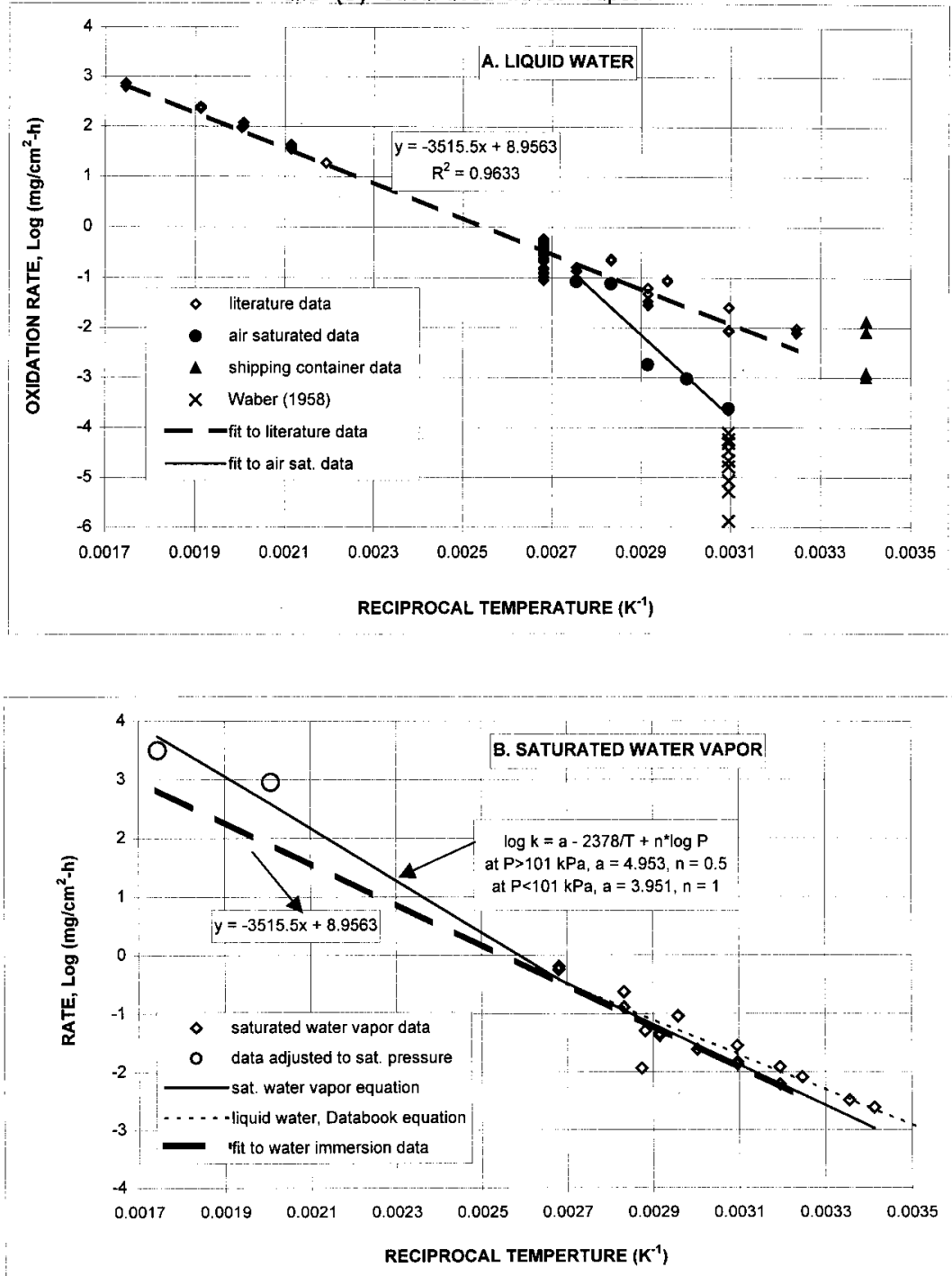
HNF-2853, Rev. 0

\subsection{COMPARISON WITH LITERATURE EQUATIONS}

Reaction rate constant equations for oxidation of uranium in liquid water and oxygen free water vapor in Revision 6 of the Technical Databook (Reilly 1998) were obtained from the literature (Ritchie 1981, Pearce 1989, Hayward 1994). These equations include the following:

for 1 iquid water at temperature (T) $<373 \mathrm{~K}$

$$
\log K=7.634-3016 / T
$$

for water vapor at $\mathrm{T}<523 \mathrm{~K}$

$$
\log K=4.33-2144 / T+0.5 \log (P)
$$

for water vapor at $523<\mathrm{T}<735 \mathrm{~K}$ and $43 \mathrm{kPa}$ to $93 \mathrm{kPa}$

$$
\log K=-22.915+30,066 / T-9,119,078 / T^{2}
$$

for water vapor at $735<\mathrm{T}<923 \mathrm{~K}$ and $43 \mathrm{kPa}$ to $93 \mathrm{kPa}$

$$
\log K=-23.905+42,718 / T-17,875,810 / T^{2}
$$

where $K$ is reaction rate constant in units of $\mathrm{mg} / \mathrm{cm}^{2}-\mathrm{h}$, $T$ is temperature in degress $K$ and $P$ is water vapor pressure in $\mathrm{kPa}$.

The Databook equation for liquid water reaction rate constant is compared to the literature review data and data fit on Figure $5 b$.

The Databook equations for water vapor reaction rate constant are compared to the literature review data on Figure $6 \mathrm{a}$. The equation for $\mathrm{T}<523 \mathrm{~K}$ was evaluated at $43 \mathrm{kPa}$ and at $93 \mathrm{kPa}$ to be consistent with the range of pressures represented by the equations for $T>523 \mathrm{~K}$. The literature review data on Figure $6 a$ were normalized to a pressure of $70 \mathrm{kPa}$ as follows: $k^{\prime}=k(70 / P)^{0.5}$. Also shown for reference on Figure $6 a$ are the regression lines from the review data (Equations 5.3, 5.7, and 5.9) evaluated at $70 \mathrm{kPa}$.

Figure $6 \mathrm{~b}$ shows the Databook and the review data equation 1 ines (Equation 5.3) for $12 \mathrm{kPa}$ water vapor, saturation at $50^{\circ} \mathrm{C}$. Also shown are the literature review data in the range of $7 \mathrm{kPa}$ to $20 \mathrm{kPa}$.

\subsection{CONCLUSIONS}

The literature review data for uranium reaction rate constant in liquid water and oxygen free water vapor over a wide range of temperature and pressure can be represented by Equations 5.4, 5.5, 5.7, 5.9, 5.10, and 5.11. At temperature below about $200{ }^{\circ} \mathrm{C}$ these recommended equations are in good agreement with the literature equations in Revision 6 of the Technical Databook (Rei11y 1998). 
HNF-2853, Rev. 0

Figure 6. Comparison of Literature Equations Used in the Technical Databook, Literature Review Data, and the Line Fit to the Review Data.

(a) At high vapor pressures and (b) at low vapor pressure.

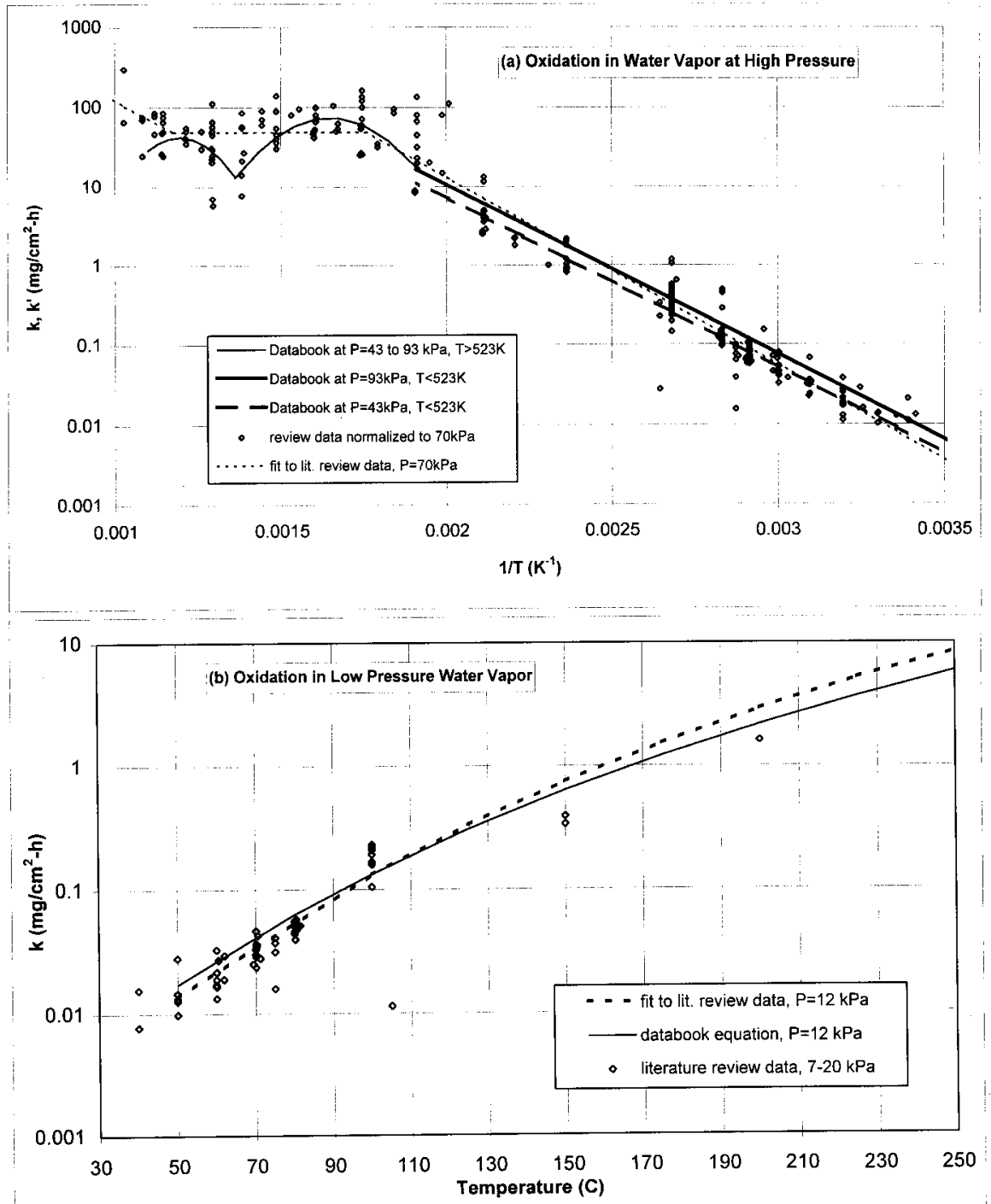




\subsection{REFERENCES}

Abrefah, J., H. C. Buchanan, W. M. Gerry, W. J. Gray, and S. C. Marschman, 1998, Dry Air Oxidation Kinetics of $K$ Basin Spent Nuclear Fuel, PNNL-11786, Pacific Northwest National Laboratory, Richland, Washington.

Baker, M. McD., L. N. Less and S. Orman, 1981, Undocumented Data Reported by Ritchie.

Baker, M. McD., L. N. Less, and S. Orman, 1966, "Uranium+Water Reaction, Part 1-Kinetics, Products, and Mechanism, "Transactions of the Faraday Society, Vol. 62, p. 2513.

Baker, M. McD., J. W. Bleloch, N. Less, and S. Orman, 1964, Uranium Compatibi7ity Studies; Part 3: The Influence of Oxygen on the UraniumWater Reaction, AWRE Report No. 0-40/64, Atomic Weapons Research Establishment, United Kingdom Atomic Energy Authority, United Kingdom.

Bensen, N., R. P. Straetz, and J. E. Draley, 1945, Autoclave Tests of Uranium Slugs and Alloys, CT-3043, University of Chicago, Chicago, Illinois.

Colbeck, E. W., H. J. Spencer-Palmer, et al., 1945, Some Preliminary Experiments on Possible Methods of Protecting U Metal Against Corrosion, BR-549, Imperial Chemical Industries Limited, United Kingdom.

Colmenares, C. A., 1984, "Oxidation of Mechanisms and Catalytic Properties of the Actinides," Progress in Solid State Chemistry, Vol. 15, pp. 257-364.

Cooper, T. D., 1997, SNF Project Recommended Reaction Rate Constants for Corrosion of $N$ Reactor Fuel, HNF-SD-SNF-TI-020, Rev. 1, B\&W Hanford Company, Richland, Washington.

Corcoran, V. J., C. Johnston, W. J. Metcalfe, and J. Thorpe, 1965, The Water Vapor Corrosion of Uranium and its Prevention, AWRE Report No. 0-42/65, Atomic Weapons Research Establishment, United Kingdom Atomic Energy Authority, United Kingdom.

Draley, J. E., and G. C. English, 1945, Corrosion Research-Uranium and Alloys, CT-1943, University of Chicago, Chicago, Illinois.

Greninger, A. B., et al., 1945, "Metallurgical Laboratory Monthly Report," Metallurgy Division, CT-2925, University of Chicago, Chicago, Illinois.

Grimes, J. H., and J. R. Morris, 1965, Uranium Corrosion Studies, Part 2: The Rate of Reaction of Polished Uranium and Water Vapour at Various Temperatures, AWRE Report No. 0-68/65, Atomic Weapons Research Establishment, United Kingdom Atomic Energy Authority, United Kingdom.

Hayward, P. J., D. G. Evans, P. Taylor, I. M. George, and A. M. Duclos, 1994, "Oxidation of Uranium in Steam," Journal of Nuclear Materials, Vol. 217, pp. 82-92. 


\subsection{REFERENCES (Continued)}

Hopkinson, B. E., 1959, "Kinetics of the Uranium-Steam Reaction, "Journal of the Electrochemical Society, Vol. 106.

Huddle, R. A. U., 1953, The Uranium-Steam Reaction, AERE-M/R-1281, Atomic Energy Research Establishment, Harwe11, Berks, England.

Jackson, R. L., and J. B. Condon, 1977, Uranium/Water Vapor Reactions in Gaseous Atmospheres, Report Number Y-2078, Oak Ridge Y-12 Plant, Oak Ridge, Tennessee.

Kondo, T., E. D. Verink, F. H. Beck, and M. G. Fontana, 1974, "A Gas Chromatographic Study on the Kinetics of Uranium Oxidation in Moist Environments," Corrosion, Vol. 30, No. 9, p. 330.

Kondo, T., E. D. Verink, F. H. Beck, and M. G. Fontana, 1964, "Gas Chromatographic and Gravimetric Studies of Uranium Oxidation Mechanism," Corrosion, Vol. 20, p. 314t.

Lemmon, A. W. Jr., 1957, The Reaction of Steam with Uranium and with Various Uranium-Niobium-Zirconium Alloys at High Temperatures, Report No. BMI-1192, Battelle Memorial Institute, Columbus, Ohio.

Magnani, N. J., 1974, The Reaction of Uranium and its Alloys with Water Vapor at Low Temperatures, SAND-74-0145, Sandia Laboratories.

McWhirter, J. W. and J. E. Draley, 1952, Aqueous Corrosion of Uranium and Alloys: Survey of Project Literature, ANL-4862, Argonne National Laboratory, Chicago, Illinois.

Mollison, W. A., G. C. English, and F. Nelson, 1945, Corrosion of Uranium in Distilled Water, CT-3055, University of Chicago, Chicago, I1linois.

Orman, S., 1964, Uranium Compatibility Studies, Part 2: The Effect of Water Vapour Pressure in an Oxygen Free Atmosphere on the Corrosion Rate of Uranium at $100{ }^{\circ} \mathrm{C}$, AWRE Report No. $0-25 / 64$, United Kingdom Atomic Energy Authority, United, Kingdom.

Orman, S., and P. Walker, 1964, Undocumented Data reported by Ritchie (1981) and Pearce (1989).

Orman, S., 1963, "The Effect of Certain Gases on the Rate of 0xidation of Uranium by Water Vapor," Chemistry and Industry, p. 1692.

Orman, S., 1963, Atomic Weapons Research Estab7ishment, AWRE Report No. 0-94/63, United Kingdom Atomic Energy Authority, United, Kingdom.

Orman, S., 1961, Undocumented Data reported by Ritchie (1981) and Pearce (1989). 


\subsection{REFERENCES (Continued)}

Pajunen, A. L., 1998, Cask Loading Technical Manual, HNF-2169, (Draft), Duke Engineering \& Services Hanford, Inc., Richland, Washington.

Pearce, R. J., 1989, A Review of the Rates of Reaction of Unirradiated Uranium in Gaseous Atmospheres, RD/B/6231/R86, Central Electric Generating Board, Berkeley Nuclear Laboratories, United Kingdom.

Pearce, R. J., and P. Kay, 1987, The Reaction of Uranium in the $\mathrm{U}-\mathrm{O}_{2}-\mathrm{H}_{2} \mathrm{O}$ and $U-H_{2} \mathrm{O}$ systems, TPRD/B/0954/R87, Central Electric Generating Board, Berkeley Nuclear Laboratories, United Kingdom.

Reilly, M. A., 1998, Spent Nuclear Fuel Project Technical Databook, HNF-SD-SNF-TI-015, Rev. 6, Duke Engineering \& Services Hanford, Inc., Richland, Washington.

Ritchie, A. G., R. C. Greenwood, S. J. Randles, D. R. Netherton, and J. P. Whitehorn, 1986, "Measurements of the Rate of the Uranium-Water Vapour Reaction, "Journal of Nuclear Materials, Vol. 140, pp. 197-201.

Ritchie, A. G., 1984, "The Kinetics and Mechanism of the Uranium-Water Vapour Reaction--An Evaluation of Some Publ ished Work, " Journal of Nuclear Materials, Vol. 120, pp. 143-153.

Ritchie, A. G., 1981, "A Review of the Rates of Reaction of Uranium with Oxygen and Water Vapor at Temperatures Up to $300^{\circ} \mathrm{C}$, "Journal of Nuclear Material, Vo1. 102, pp. 170-182.

Schroeder, J. B., D. A. Vaughan, and C. M. Schwartz, 1959, "Aqueous Uranium Corrosion at $100{ }^{\circ} \mathrm{C}, "$ Journal of the Electrochemical Society, Vo1. 106 , No. 6 .

Scott, A. J., 1959, Fission Product Release by the High Temperature UraniumSteam Reaction, HW-62604, General Electric Company, Hanford Atomic Works, Rich 1 and, Washington.

Trimble, D. J., 1998, Reaction Rate Constant for Dry Air Oxidation of K Basin Fuel, HNF-SD-SNF-CN-019, Rev. 0, Duke Engineering \& Services Hanford, Inc., Richland, Washington.

Troutner, V. H., 1960, Mechanisms and Kinetics of Uranium Corrosion and Uranium Core Fuel Element Ruptures in Water and Steam, HW-67370, General Electric Company, Hanford Atomic Works, Richland, Washington.

Waber, J. T., 1958, A Review of the Corrosion Behavior of Uranium, LA-2035, Los Alamos National Laboratory, Los Alamos, New Mexico.

Waber, J. T., 1952, A Review of the Corrosion of Uranium and its Alloys, LA-1524, Los Alamos National Laboratory, Los Alamos, New Mexico. 
HNF-2853, Rev. 0

\subsection{REFERENCES (Continued)}

Wathen, T., 1943, Corrosion of Uranium Metal in Air and Steam at Various Temperatures $(R / G C / 1304)$, BR-223A, Imperial Chemical Industries Limited, United Kingdom.

Weirick, L. J., 1984, The Oxidation of Uranium in Low Partial Pressures of Oxygen and Water Vapor at $100{ }^{\circ} \mathrm{C}$, SAND83-0618, Sandia National Laboratories, Albuquerque, New Mexico. 
HNF-2853, Rev. 0

\section{APPENDIX A}

\section{DATA BASE FOR OXIDATION OF URANIUM IN WATER AND OXYGEN FREE WATER VAPOR}

Table Al contains the data for oxidation of uranium in oxygen free water vapor.

Table A2 contains the data for oxidation of uranium in liquid water. 
HNF-2853, Rev. 0

This page intentionally left blank. 
HNF-2853, Rev. 0

Table Al. Oxidation of Uranium in Oxygen Free Water Vapor.

\begin{tabular}{|c|c|c|c|c|c|}
\hline \multicolumn{3}{|c|}{ Temperature } & \multirow{2}{*}{$\begin{array}{c}\text { Water Vapor } \\
\text { Pressure } \\
\text { (kPa) }\end{array}$} & \multirow{2}{*}{$\begin{array}{c}\text { Oxidation } \\
\text { Rate } \\
\left(\mathrm{mg} / \mathrm{cm}^{2}-\mathrm{h}\right) \\
\end{array}$} & \multirow[b]{2}{*}{ Reference } \\
\hline$\left({ }^{\circ} \mathrm{C}\right)$ & $(K)$ & $\left(\mathrm{K}^{-1}\right)$ & & & \\
\hline 65 & 338 & 0.00296 & 25.0 & 0.091 & Baker et a]. (1964) \\
\hline 80 & 353 & 0.00283 & 47.3 & 0.233 & Baker et al. (1964) \\
\hline 100 & 373 & 0.00268 & 3.32 & 0.059 & Baker et al. (1964) \\
\hline 100 & 373 & 0.00268 & 6.64 & 0.086 & Baker et a1. (1964) \\
\hline 100 & 373 & 0.00268 & 13.3 & 0.11 & Baker et al. (1964) \\
\hline 100 & 373 & 0.00268 & 26.6 & 0.15 & Baker et a1. (1964) \\
\hline 100 & 373 & 0.00268 & 53.2 & 0.2 & Baker et a1. (1964) \\
\hline 100 & 373 & 0.00268 & 80 & 0.349 & Baker et al. (1964) \\
\hline 100 & 373 & 0.00268 & 93 & 0.341 & Baker et a1. (1964) \\
\hline 100 & 373 & 0.00268 & 101 & 0.638 & Baker et al. (1964) \\
\hline 80 & 353 & 0.00283 & 47.2 & 0.12773 & Baker et al. (1965) \\
\hline 100 & 373 & 0.00268 & 0.61 & 0.01345 & Besson and Santon (1963) \\
\hline 62 & 335 & 0.00299 & 7.97 & 0.024 & Colmenares (1984) \\
\hline 80 & 353 & 0.00283 & 7.97 & 0.045 & Colmenares (1984) \\
\hline 100 & 373 & 0.00268 & 0.0065 & 0.0055 & Colmenares (1984) \\
\hline 100 & 373 & 0.00268 & 0.012 & 0.007 & Colmenares (1984) \\
\hline 100 & 373 & 0.00268 & 0.07 & 0.0075 & Colmenares (1984) \\
\hline 100 & 373 & 0.00268 & 0.30 & 0.03 & Colmenares (1984) \\
\hline 100 & 373 & 0.00268 & 1.50 & 0.055 & Colmenares (1984) \\
\hline 100 & 373 & 0.00268 & 3.00 & 0.085 & Colmenares (1984) \\
\hline 100 & 373 & 0.00268 & 5.00 & 0.12 & Colmenares (1984) \\
\hline 100 & 373 & 0.00268 & 8.5 & 0.14 & Colmenares (1984) \\
\hline 100 & 373 & 0.00268 & 8.5 & 0.16 & Colmenares (1984) \\
\hline 100 & 373 & 0.00268 & 13.3 & 0.167 & Colmenares (1984) \\
\hline 100 & 373 & 0.00268 & 13.3 & 0.217 & Colmenares (1984) \\
\hline 100 & 373 & 0.00268 & 13.3 & 0.225 & Colmenares (1984) \\
\hline 100 & 373 & 0.00268 & 13.3 & 0.23 & Colmenares (1984) \\
\hline 100 & 373 & 0.00268 & 13.3 & 0.24 & Colmenares (1984) \\
\hline
\end{tabular}


HNF-2853, Rev. 0

Table Al. Oxidation of Uranium in Oxygen Free Water Vapor. (Continued)

\begin{tabular}{|c|c|c|c|c|c|}
\hline \multicolumn{3}{|c|}{ Temperature } & \multirow{2}{*}{$\begin{array}{c}\text { Water Vapor } \\
\text { Pressure } \\
(\mathrm{kPa})\end{array}$} & \multirow{2}{*}{$\begin{array}{c}\text { Oxidation } \\
\text { Rate } \\
\left(\mathrm{mg} / \mathrm{cm}^{2}-\mathrm{h}\right)\end{array}$} & \multirow[b]{2}{*}{ Reference } \\
\hline$\left({ }^{\circ} \mathrm{C}\right)$ & $(K)$ & $\left(K^{-1}\right)$ & & & \\
\hline 25 & 298 & 0.00336 & 4.52 & 0.00323 & Corcoran et a1. (1965) \\
\hline 40 & 313 & 0.00319 & 3.19 & 0.00578 & Corcoran et a1. (1965) \\
\hline 40 & 313 & 0.00319 & 2.33 & 0.00457 & Grimes and Morris (1965) \\
\hline 199 & 472 & 0.00212 & 101 & 3.42 & Hayward et al. (1994) \\
\hline 199 & 472 & 0.00212 & 101 & 4.87 & Hayward et al. (1994) \\
\hline 200 & 473 & 0.00211 & 101 & 4.96 & Hayward et al. (1994) \\
\hline 201 & 474 & 0.00211 & 101 & 2.99 & Hayward et a1. (1994) \\
\hline 201 & 474 & 0.00211 & 101 & 3.07 & Hayward et al. (1994) \\
\hline 201 & 474 & 0.00211 & 101 & 3.23 & Hayward et a1. (1994) \\
\hline 250 & 523 & 0.00191 & 101 & 20.3 & Hayward et al. (1994) \\
\hline 250 & 523 & 0.00191 & 101 & 23.8 & Hayward et al. (1994) \\
\hline 252 & 525 & 0.0019 & 101 & 10.1 & Hayward et a1. (1994) \\
\hline 252 & 525 & 0.0019 & 101 & 10.7 & Hayward et al. (1994) \\
\hline 285 & 558 & 0.00179 & 101 & 38.2 & Hayward et a1. (1994) \\
\hline 285 & 558 & 0.00179 & 101 & 42.0 & Hayward et a1. (1994) \\
\hline 301 & 574 & 0.00174 & 101 & 32.2 & Hayward et a1. (1994) \\
\hline 301 & 574 & 0.00174 & 101 & 64.5 & Hayward et al. (1994) \\
\hline 301 & 574 & 0.00174 & 101 & 70.7 & Hayward et al. (1994) \\
\hline 302 & 575 & 0.00174 & 101 & 30.3 & Hayward et a1. (1994) \\
\hline 325 & 598 & 0.00167 & 101 & 64.6 & Hayward et al. (1994) \\
\hline 327 & 600 & 0.00167 & 101 & 59.9 & Hayward et al. (1994) \\
\hline 349 & 622 & 0.00161 & 101 & 87.1 & Hayward et al. (1994) \\
\hline 350 & 623 & 0.00161 & 101 & 78.9 & Hayward et al. (1994) \\
\hline 351 & 624 & 0.00160 & 101 & 63.0 & Hayward et al. (1994) \\
\hline 352 & 625 & 0.00160 & 101 & 50.4 & Hayward et al. (1994) \\
\hline 352 & 625 & 0.00160 & 101 & 59.9 & Hayward et al. (1994) \\
\hline 353 & 626 & 0.00160 & 101 & 55.5 & Hayward et al. (1994) \\
\hline 400 & 673 & 0.00149 & 101 & 43.4 & Hayward et a1. (1994) \\
\hline
\end{tabular}


Table Al. Oxidation of Uranium in Oxygen Free Water Vapor. (Continued)

\begin{tabular}{|c|c|c|c|c|c|}
\hline \multicolumn{3}{|c|}{ Temperature } & \multirow{2}{*}{$\begin{array}{c}\text { Water Vapor } \\
\text { Pressure } \\
(\mathrm{kPa})\end{array}$} & \multirow{2}{*}{$\begin{array}{c}\text { Oxidation } \\
\text { Rate } \\
\left(\mathrm{mg} / \mathrm{cm}^{2}-\mathrm{h}\right)\end{array}$} & \multirow[b]{2}{*}{ Reference } \\
\hline$\left({ }^{\circ} \mathrm{C}\right)$ & $(K)$ & $\left(K^{-1}\right)$ & & & \\
\hline 400 & 673 & 0.00149 & 101 & 54.5 & Hayward et a1. (1994) \\
\hline 400 & 673 & 0.00149 & 101 & 65.4 & Hayward et al. (1994) \\
\hline 447 & 720 & 0.00139 & 101 & 32.5 & Hayward et al. (1994) \\
\hline 450 & 723 & 0.00138 & 101 & 25.7 & Hayward et al. (1994) \\
\hline 451 & 724 & 0.00138 & 101 & 9.28 & Hayward et al. (1994) \\
\hline 451 & 724 & 0.00138 & 101 & 16.9 & Hayward et al. (1994) \\
\hline 499 & 772 & 0.0013 & 101 & 6.92 & Hayward et a1. (1994) \\
\hline 500 & 773 & 0.00129 & 101 & 8.42 & Hayward et al. (1994) \\
\hline 501 & 774 & 0.00129 & 101 & 24.5 & Hayward et a1. (1994) \\
\hline 501 & 774 & 0.00129 & 101 & 27.1 & Hayward et al. (1994) \\
\hline 502 & 775 & 0.00129 & 101 & 36.8 & Hayward et al. (1994) \\
\hline 552 & 825 & 0.00121 & 101 & 49.0 & Hayward et al. (1994) \\
\hline 600 & 873 & 0.00115 & 101 & 29.7 & Hayward et a1. (1994) \\
\hline 602 & 875 & 0.00114 & 101 & 57.8 & Hayward et a1. (1994) \\
\hline 603 & 876 & 0.00114 & 101 & 31.7 & Hayward et al. (1994) \\
\hline 650 & 923 & 0.00108 & 101 & 29.7 & Hayward et a1. (1994) \\
\hline 160 & 433 & 0.00231 & 101 & 1.20 & Hopkinson (1959) \\
\hline 200 & 473 & 0.00211 & 101 & 4.80 & Hopkinson (1959) \\
\hline 200 & 473 & 0.00211 & 101 & 6.00 & Hopkinson (1959) \\
\hline 200 & 473 & 0.00211 & 101 & 6.00 & Hopkinson (1959) \\
\hline 230 & 503 & 0.00199 & 101 & 18 & Hopkinson (1959) \\
\hline 230 & 503 & 0.00199 & 101 & 18 & Hopkinson (1959) \\
\hline 230 & 503 & 0.00199 & 101 & 96 & Hopkinson (1959) \\
\hline 250 & 523 & 0.00191 & 101 & 54 & Hopkinson (1959) \\
\hline 250 & 523 & 0.00191 & 101 & 96 & Hopkinson (1959) \\
\hline 250 & 523 & 0.00191 & 101 & 96 & Hopkinson (1959) \\
\hline 270 & 543 & 0.00184 & 101 & 102 & Hopkinson (1959) \\
\hline 270 & 543 & 0.00184 & 101 & 114 & Hopkinson (1959) \\
\hline
\end{tabular}


Table A1. Oxidation of Uranium in 0xygen Free Water Vapor. (Continued)

\begin{tabular}{|c|c|c|c|c|c|}
\hline \multicolumn{3}{|c|}{ Temperature } & \multirow{2}{*}{$\begin{array}{c}\text { Water Vapor } \\
\text { Pressure } \\
(\mathrm{kPa})\end{array}$} & \multirow{2}{*}{$\begin{array}{c}\text { Oxidation } \\
\text { Rate } \\
\left(\mathrm{mg} / \mathrm{cm}^{2}-\mathrm{h}\right)\end{array}$} & \multirow[b]{2}{*}{ Reference } \\
\hline$\left({ }^{\circ} \mathrm{C}\right)$ & (K) & $\left(K^{-1}\right)$ & & & \\
\hline 270 & 543 & 0.00184 & 101 & 114 & Hopkinson (1959) \\
\hline 300 & 573 & 0.00175 & 101 & 120 & Hopkinson (1959) \\
\hline 300 & 573 & 0.00175 & 101 & 144 & Hopkinson (1959) \\
\hline 300 & 573 & 0.00175 & 101 & 162 & Hopkinson (1959) \\
\hline 330 & 603 & 0.00166 & 101 & 126 & Hopkinson (1959) \\
\hline 350 & 623 & 0.00161 & 101 & 96 & Hopkinson (1959) \\
\hline 370 & 643 & 0.00156 & 101 & 114 & Hopkinson (1959) \\
\hline 380 & 653 & 0.00153 & 101 & 96 & Hopkinson (1959) \\
\hline 400 & 673 & 0.00149 & 101 & 108 & Hopkinson (1959) \\
\hline 420 & 693 & 0.00144 & 101 & 72 & Hopkinson (1959) \\
\hline 420 & 693 & 0.00144 & 101 & 84 & Hopkinson (1959) \\
\hline 420 & 693 & 0.00144 & 101 & 108 & Hopkinson (1959) \\
\hline 450 & 723 & 0.00138 & 101 & 66 & Hopkinson (1959) \\
\hline 450 & 723 & 0.00138 & 101 & 102 & Hopkinson (1959) \\
\hline 500 & 773 & 0.00129 & 101 & 54 & Hopkinson (1959) \\
\hline 500 & 773 & 0.00129 & 101 & 60 & Hopkinson (1959) \\
\hline 500 & 773 & 0.00129 & 101 & 78 & Hopkinson (1959) \\
\hline 520 & 793 & 0.00126 & 101 & 36 & Hopkinson (1959) \\
\hline 520 & 793 & 0.00126 & 101 & 60 & Hopkinson (1959) \\
\hline 550 & 823 & 0.00122 & 101 & 42 & Hopkinson (1959) \\
\hline 550 & 823 & 0.00122 & 101 & 48 & Hopkinson (1959) \\
\hline 550 & 823 & 0.00122 & 101 & 60 & Hopkinson (1959) \\
\hline 550 & 823 & 0.00122 & 101 & 66 & Hopkinson (1959) \\
\hline 600 & 873 & 0.00115 & 101 & 78 & Hopkinson (1959) \\
\hline 600 & 873 & 0.00115 & 101 & 90 & Hopkinson (1959) \\
\hline 600 & 873 & 0.00115 & 101 & 102 & Hopkinson (1959) \\
\hline 650 & 923 & 0.00108 & 101 & 84 & Hopkinson (1959) \\
\hline 650 & 923 & 0.00108 & 101 & 90 & Hopkinson (1959) \\
\hline
\end{tabular}


HNF-2853, Rev. 0

Table A1. Oxidation of Uranium in Oxygen Free Water Vapor. (Continued)

\begin{tabular}{|c|c|c|c|c|c|}
\hline \multicolumn{3}{|c|}{ Temperature } & \multirow{2}{*}{$\begin{array}{c}\text { Water Vapor } \\
\text { Pressure } \\
(\mathrm{kPa})\end{array}$} & \multirow{2}{*}{$\begin{array}{c}\text { Oxidation } \\
\text { Rate } \\
\left(\mathrm{mg} / \mathrm{cm}^{2}-\mathrm{h}\right)\end{array}$} & \multirow[b]{2}{*}{ Reference } \\
\hline$\left({ }^{\circ} \mathrm{C}\right)$ & $(K)$ & $\left(K^{-1}\right)$ & & & \\
\hline 700 & 973 & 0.00103 & 101 & 78 & Hopkinson (1959) \\
\hline 700 & 973 & 0.00103 & 101 & 360 & Hopkinson (1959) \\
\hline 730 & 1003 & 0.00100 & 101 & 360 & Hopkinson (1959) \\
\hline 780 & 1053 & 0.00095 & 101 & 240 & Hopkinson (1959) \\
\hline 820 & 1093 & 0.00091 & 101 & 180 & Hopkinson (1959) \\
\hline 840 & 1113 & 0.0009 & 101 & 180 & Hopkinson (1959) \\
\hline 880 & 1153 & 0.00087 & 101 & 12 & Hopkinson (1959) \\
\hline 890 & 1163 & 0.00086 & 101 & 18 & Hopkinson (1959) \\
\hline 930 & 1203 & 0.00083 & 101 & 18 & Hopkinson (1959) \\
\hline 970 & 1243 & 0.00080 & 101 & 12 & Hopkinson (1959) \\
\hline 970 & 1243 & 0.00080 & 101 & 18 & Hopkinson (1959) \\
\hline 1000 & 1273 & 0.00079 & 101 & 12 & Hopkinson (1959) \\
\hline 1000 & 1273 & 0.00079 & 101 & 18 & Hopkinson (1959) \\
\hline 1020 & 1293 & 0.00077 & 101 & 12 & Hopkinson (1959) \\
\hline 1020 & 1293 & 0.00077 & 101 & 18 & Hopkinson (1959) \\
\hline 1060 & 1333 & 0.00075 & 101 & 18 & Hopkinson (1959) \\
\hline 1200 & 1473 & 0.00068 & 101 & 228 & Hopkinson (1959) \\
\hline 1400 & 1673 & 0.00060 & 101 & 288 & Hopkinson (1959) \\
\hline 200 & 473 & 0.00211 & 101 & 14.0 & Huddle (1953) \\
\hline 250 & 523 & 0.00191 & 101 & 79.8 & Huddle (1953) \\
\hline 300 & 573 & 0.00175 & 101 & 70.2 & Huddle (1953) \\
\hline 350 & 623 & 0.00161 & 101 & 119 & Huddle (1953) \\
\hline 400 & 673 & 0.00149 & 101 & 106 & Huddle (1953) \\
\hline 450 & 723 & 0.00138 & 101 & 68.1 & Huddle (1953) \\
\hline 500 & 773 & 0.00129 & 101 & 68.1 & Huddle (1953) \\
\hline 600 & 873 & 0.00115 & 101 & 59.6 & Huddle (1953) \\
\hline 100 & 373 & 0.00268 & 1.59 & 0.176 & Jackson and Condon (1977) \\
\hline 100 & 373 & 0.00268 & 2.86 & 0.211 & Jackson and Condon (1977) \\
\hline
\end{tabular}


Table A1. 0xidation of Uranium in Oxygen Free Water Vapor. (Continued)

\begin{tabular}{|c|c|c|c|c|c|}
\hline \multicolumn{3}{|c|}{ Temperature } & \multirow{2}{*}{$\begin{array}{c}\text { Water Vapor } \\
\text { Pressure } \\
(\mathrm{kPa})\end{array}$} & \multirow{2}{*}{$\begin{array}{c}\text { Oxidation } \\
\text { Rate } \\
\left(\mathrm{mg} / \mathrm{cm}^{2}-\mathrm{h}\right) \\
\end{array}$} & \multirow[b]{2}{*}{ Reference } \\
\hline$\left({ }^{\circ} \mathrm{C}\right)$ & (K) & $\left(K^{-1}\right)$ & & & \\
\hline 150 & 423 & 0.00236 & 0.40 & 0.0779 & Jackson and Condon (1977) \\
\hline 150 & 423 & 0.00236 & 1.59 & 0.325 & Jackson and Condon (1977) \\
\hline 150 & 423 & 0.00236 & 2.86 & 0.406 & Jackson and Condon (1977) \\
\hline 75 & 348 & 0.00287 & 4.39 & 0.0226 & Kondo (1964) \\
\hline 75 & 348 & 0.00287 & 5.32 & 0.0175 & Kondo (1964) \\
\hline 75 & 348 & 0.00287 & 7.97 & 0.0255 & Kondo (1964) \\
\hline 75 & 348 & 0.00287 & 10.63 & 0.0350 & Kondo (1964) \\
\hline 75 & 348 & 0.00287 & 13.29 & 0.0430 & Kondo (1964) \\
\hline 80 & 353 & 0.00283 & 0.40 & 0.0336 & Kondo (1964) \\
\hline 80 & 353 & 0.00283 & 1.59 & 0.0740 & Kondo (1964) \\
\hline 80 & 353 & 0.00283 & 2.86 & 0.0928 & Kondo (1964) \\
\hline 98 & 371 & 0.0027 & 0.40 & 0.0484 & Kondo (1964) \\
\hline 60 & 333 & 0.00300 & 11.03 & 0.0207 & Kondo (1974) \\
\hline 800 & 1073 & 0.00093 & 344 & 29.0 & Lemmon (1957) \\
\hline 800 & 1073 & 0.00093 & 344 & 41.8 & Lemmon (1957) \\
\hline 800 & 1073 & 0.00093 & 344 & 57.8 & Lemmon (1957) \\
\hline 800 & 1073 & 0.00093 & 344 & 78.0 & Lemmon (1957) \\
\hline 800 & 1073 & 0.00093 & 344 & 98.6 & Lemmon (1957) \\
\hline 800 & 1073 & 0.00093 & 344 & 101 & Lemmon (1957) \\
\hline 900 & 1173 & 0.00085 & 344 & 71 & Lemmon (1957) \\
\hline 9.00 & 1173 & 0.00085 & 344 & 98 & Lemmon (1957) \\
\hline 900 & 1173 & 0.00085 & 344 & 137 & Lemmon (1957) \\
\hline 900 & 1173 & 0.00085 & 344 & 214 & Lemmon (1957) \\
\hline 900 & 1173 & 0.00085 & 344 & 287 & Lemmon (1957) \\
\hline 900 & 1173 & 0.00085 & 344 & 411 & Lemmon (1957) \\
\hline 1000 & 1273 & 0.00079 & 344 & 68 & Lemmon (1957) \\
\hline 1000 & 1273 & 0.00079 & 344 & 101 & Lemmon (1957) \\
\hline 1000 & 1273 & 0.00079 & 344 & 146 & Lemmon (1957) \\
\hline
\end{tabular}


HNF-2853, Rev. 0

Table A1. Oxidation of Uranium in 0xygen Free Water Vapor. (Continued)

\begin{tabular}{|c|c|c|c|c|c|}
\hline \multicolumn{3}{|c|}{ Temperature } & \multirow{2}{*}{$\begin{array}{c}\text { Water Vapor } \\
\text { Pressure } \\
\text { (kPa) }\end{array}$} & \multirow{2}{*}{$\begin{array}{c}\text { Oxidation } \\
\text { Rate } \\
\left(\mathrm{mg} / \mathrm{cm}^{2}-\mathrm{h}\right)\end{array}$} & \multirow[b]{2}{*}{ Reference } \\
\hline$\left({ }^{\circ} \mathrm{C}\right)$ & (K) & $\left(K^{-1}\right)$ & & & \\
\hline 1000 & 1273 & 0.00079 & 344 & 238 & Lemmon (1957) \\
\hline 1000 & 1273 & 0.00079 & 344 & 347 & Lemmon (1957) \\
\hline 1125 & 1398 & 0.00072 & 344 & 398 & Lemmon (1957) \\
\hline 1125 & 1398 & 0.00072 & 344 & 488 & Lemmon (1957) \\
\hline 1125 & 1398 & 0.00072 & 344 & 514 & Lemmon (1957) \\
\hline 1230 & 1503 & 0.00067 & 344 & 283 & Lemmon (1957) \\
\hline 1230 & 1503 & 0.00067 & 344 & 386 & Lemmon (1957) \\
\hline 1230 & 1503 & 0.00067 & 344 & 471 & Lemmon (1957) \\
\hline 1230 & 1503 & 0.00067 & 344 & 535 & Lemmon (1957) \\
\hline 1230 & 1503 & 0.00067 & 344 & 535 & Lemmon (1957) \\
\hline 1280 & 1553 & 0.00064 & 344 & 246 & Lemmon (1957) \\
\hline 1280 & 1553 & 0.00064 & 344 & 343 & Lemmon (1957) \\
\hline 1280 & 1553 & 0.00064 & 344 & 394 & Lemmon (1957) \\
\hline 1280 & 1553 & 0.00064 & 344 & 579 & Lemmon (1957) \\
\hline 1280 & 1553 & 0.00064 & 344 & 600 & Lemmon (1957) \\
\hline 75 & 348 & 0.00287 & 38.41 & 0.0114 & Magnani (1974) \\
\hline 35 & 308 & 0.00325 & 5.58 & 0.00807 & Orman (1963) \\
\hline 50 & 323 & 0.00310 & 12.36 & 0.0282 & Orman (1963) \\
\hline 65 & 338 & 0.00296 & 24.98 & 0.0914 & Orman (1963) \\
\hline 70 & 343 & 0.00292 & 31.06 & 0.0417 & Orman (1963) \\
\hline 70 & 343 & 0.00292 & 31.06 & 0.0457 & Orman (1963) \\
\hline 80 & 353 & 0.00283 & 47 & 0.234 & Orman (1963) \\
\hline 100 & 373 & 0.00268 & 101 & 0.639 & Orman (1963) \\
\hline 100 & 373 & 0.00268 & 0.94 & 0.0229 & Orman (1964) \\
\hline 100 & 373 & 0.00268 & 1.30 & 0.0578 & Orman (1964) \\
\hline 100 & 373 & 0.00268 & 2.22 & 0.0659 & Orman (1964) \\
\hline 100 & 373 & 0.00268 & 2.78 & 0.0645 & Orman (1964) \\
\hline 100 & 373 & 0.00268 & 3.16 & 0.0981 & Orman (1964) \\
\hline
\end{tabular}


Table Al, Oxidation of Uranium in 0xygen Free Water Vapor. (Continued)

\begin{tabular}{|c|c|c|c|c|c|}
\hline \multicolumn{3}{|c|}{ Temperature } & \multirow{2}{*}{$\begin{array}{c}\text { Water Vapor } \\
\text { Pressure } \\
(\mathrm{kPa})\end{array}$} & \multirow{2}{*}{$\begin{array}{c}\text { Oxidation } \\
\text { Rate } \\
\left(\mathrm{mg} / \mathrm{cm}^{2}-\mathrm{h}\right)\end{array}$} & \multirow[b]{2}{*}{ Reference } \\
\hline$\left({ }^{\circ} \mathrm{C}\right)$ & (K) & $\left(K^{-1}\right)$ & & & \\
\hline 100 & 373 & 0.00268 & 23 & 0.234 & Orman (1964) \\
\hline 100 & 373 & 0.00268 & 42 & 0.269 & Orman (1964) \\
\hline 100 & 373 & 0.00268 & 50.9 & 0.211 & Orman (1964) \\
\hline 100 & 373 & 0.00268 & 57 & 0.308 & Orman (1964) \\
\hline 100 & 373 & 0.00268 & 66 & 0.352 & Orman (1964) \\
\hline 100 & 373 & 0.00268 & 70 & 0.468 & Orman (1964) \\
\hline 100 & 373 & 0.00268 & 74 & 0.427 & Orman (1964) \\
\hline 100 & 373 & 0.00268 & 81 & 0.462 & Orman (1964) \\
\hline 100 & 373 & 0.00268 & 87 & 0.505 & Orman (1964) \\
\hline 100 & 373 & 0.00268 & 92 & 0.432 & Orman (1964) \\
\hline 100 & 373 & 0.00268 & 98 & 0.531 & Orman (1964) \\
\hline 100 & 373 & 0.00268 & 99 & 0.578 & Orman (1964) \\
\hline 100 & 373 & 0.00268 & 100 & 0.583 & Orman (1964) \\
\hline 100 & 373 & 0.00268 & 100 & 0.562 & Orman (1964) \\
\hline 100 & 373 & 0.00268 & 101 & 0.639 & Orman (1964) \\
\hline 20 & 293 & 0.00341 & 2.39 & 0.00242 & Orman and Walker (1964) \\
\hline 22 & 295 & 0.00339 & 2.66 & 0.00215 & Orman and Walker (1964) \\
\hline 22 & 295 & 0.00339 & 2.66 & 0.00403 & Orman and Walker (1964) \\
\hline 40 & 313 & 0.00319 & 7.31 & 0.00605 & Orman and Walker (1964) \\
\hline 40 & 313 & 0.00319 & 7.31 & 0.0121 & Orman and Walker (1964) \\
\hline 50 & 323 & 0.0031 & 12.36 & 0.0134 & Orman and Walker (1964) \\
\hline 50 & 323 & 0.0031 & 12.36 & 0.0148 & Orman and Walker (1964) \\
\hline 60 & 333 & 0.00300 & 19.80 & 0.0242 & Orman and Walker (1964) \\
\hline 70 & 343 & 0.00292 & 31.10 & 0.0417 & Orman and Walker (1964) \\
\hline 70 & 343 & 0.00292 & 31.10 & 0.0417 & Orman and Walker (1964) \\
\hline 74 & 347 & 0.00288 & 36.81 & 0.0511 & Orman and Walker (1964) \\
\hline 74 & 347 & 0.00288 & 36.81 & 0.0511 & Orman and Walker (1964) \\
\hline 105 & 378 & 0.00265 & 20.80 & 0.015 & Pearce and Kay (1987) \\
\hline
\end{tabular}


Table Al. Oxidation of Uranium in Oxygen Free Water Vapor. (Continued)

\begin{tabular}{|c|c|c|c|c|c|}
\hline \multicolumn{3}{|c|}{ Temperature } & \multirow{2}{*}{$\begin{array}{c}\text { Water Vapor } \\
\text { Pressure } \\
(\mathrm{kPa})\end{array}$} & \multirow{2}{*}{$\begin{array}{c}\text { Oxidation } \\
\text { Rate } \\
\left(\mathrm{mg} / \mathrm{cm}^{2}-\mathrm{h}\right)\end{array}$} & \multirow[b]{2}{*}{ Reference } \\
\hline$\left({ }^{\circ} \mathrm{C}\right)$ & (K) & $\left(K^{-1}\right)$ & & & \\
\hline 105 & 378 & 0.00265 & 79 & 0.238 & Pearce and Kay (1987) \\
\hline 105 & 378 & 0.00265 & 100 & 0.40 & Pearce and Kay (1987) \\
\hline 150 & 423 & 0.00236 & 5.10 & 0.28 & Pearce and Kay (1987) \\
\hline 150 & 423 & 0.00236 & 21 & 0.44 & Pearce and Kay (1987) \\
\hline 150 & 423 & 0.00236 & 21 & 0.51 & Pearce and Kay (1987) \\
\hline 150 & 423 & 0.00236 & 49 & 0.72 & Pearce and Kay (1987) \\
\hline 150 & 423 & 0.00236 & 49 & 0.75 & Pearce and Kay (1987) \\
\hline 150 & 423 & 0.00236 & 49 & 0.77 & Pearce and Kay (1987) \\
\hline 150 & 423 & 0.00236 & 79 & 1.26 & Pearce and Kay (1987) \\
\hline 180 & 453 & 0.00221 & 49 & 1.82 & Pearce and Kay (1987) \\
\hline 180 & 453 & 0.00221 & 49 & 1.87 & Pearce and Kay (1987) \\
\hline 180 & 453 & 0.00221 & 79 & 1.90 & Pearce and Kay (1987) \\
\hline 200 & 473 & 0.00211 & 21 & 2.13 & Pearce and Kay (1987) \\
\hline 200 & 473 & 0.00211 & 49 & 3.00 & Pearce and Kay (1987) \\
\hline 200 & 473 & 0.00211 & 79 & 5.05 & Pearce and Kay (1987) \\
\hline 200 & 473 & 0.00211 & 100 & 5.85 & Pearce and Kay (1987) \\
\hline 240 & 513 & 0.00195 & 49 & 17.1 & Pearce and Kay (1987) \\
\hline 250 & 523 & 0.00191 & 49 & 17.0 & Pearce and Kay (1987) \\
\hline 250 & 523 & 0.00191 & 49 & 19.5 & Pearce and Kay (1987) \\
\hline 250 & 523 & 0.00191 & 79 & 33.7 & Pearce and Kay (1987) \\
\hline 325 & 598 & 0.00167 & 49 & 52.4 & Pearce and Kay (1987) \\
\hline 34.2 & 307.2 & 0.00326 & 2.67 & 0.00309 & Ritchie (1984) \\
\hline 40 & 313 & 0.00319 & 2.67 & 0.00417 & Ritchie (1984) \\
\hline 50 & 323 & 0.00310 & 2.67 & 0.00605 & Ritchie (1984) \\
\hline 50 & 323 & 0.00310 & 2.67 & 0.00672 & Ritchie (1984) \\
\hline 60 & 333 & 0.00300 & 2.67 & 0.0103 & Ritchie (1984) \\
\hline 60 & 333 & 0.00300 & 2.67 & 0.0105 & Ritchie (1984) \\
\hline 70 & 343 & 0.00292 & 2.67 & 0.0138 & Ritchie (1984) \\
\hline
\end{tabular}


HNF-2853, Rev. 0

Table A1. Oxidation of Uranium in 0xygen Free Water Vapor. (Continued)

\begin{tabular}{|c|c|c|c|c|c|}
\hline \multicolumn{3}{|c|}{ Temperature } & \multirow{2}{*}{$\begin{array}{c}\text { Water Vapor } \\
\text { Pressure } \\
\text { (kPa) }\end{array}$} & \multirow{2}{*}{$\begin{array}{l}\text { Oxidation } \\
\text { Rate } \\
\left(\mathrm{mg} / \mathrm{cm}^{2}-\mathrm{h}\right)\end{array}$} & \multirow[b]{2}{*}{ Reference } \\
\hline$\left({ }^{\circ} \mathrm{C}\right)$ & (K) & $\left(K^{-1}\right)$ & & & \\
\hline 70 & 343 & 0.00292 & 2.67 & 0.0165 & Ritchie (1984) \\
\hline 80 & 353 & 0.00283 & 2.67 & 0.0206 & Ritchie (1984) \\
\hline 80 & 353 & 0.00283 & 2.67 & 0.0208 & Ritchie $(1984)$ \\
\hline 30 & 303 & 0.00330 & 3.19 & 0.00296 & Ritchie (1986) \\
\hline 30.1 & 303.1 & 0.00330 & 1.22 & 0.00134 & Ritchie (1986) \\
\hline 30.1 & 303.1 & 0.00330 & 2.29 & 0.00242 & Ritchie (1986) \\
\hline 40 & 313 & 0.00319 & 1.21 & 0.00148 & Ritchie (1986) \\
\hline 40 & 313 & 0.00319 & 1.31 & 0.00175 & Ritchie (1986) \\
\hline 40 & 313 & 0.00319 & 2.84 & 0.00417 & Ritchie (1986) \\
\hline 40 & 313 & 0.00319 & 4.24 & 0.00417 & Ritchie (1986) \\
\hline 40 & 313 & 0.00319 & 4.24 & 0.0043 & Ritchie (1986) \\
\hline 40 & 313 & 0.00319 & 4.24 & 0.00457 & Ritchie (1986) \\
\hline 40 & 313 & 0.00319 & 5.53 & 0.00497 & Ritchie (1986) \\
\hline 49.5 & 322.5 & 0.00310 & 1.22 & 0.00444 & Ritchie (1986) \\
\hline 49.9 & 322.9 & 0.00310 & 7.65 & 0.0116 & Ritchie (1986) \\
\hline 50 & 323 & 0.00310 & 7.37 & 0.00998 & Ritchie (1986) \\
\hline 50 & 323 & 0.00310 & 9.38 & 0.00874 & Ritchie (1986) \\
\hline 50.1 & 323.1 & 0.00310 & 1.23 & 0.00471 & Ritchie (1986) \\
\hline 50.1 & 323.1 & 0.00310 & 4.34 & 0.00789 & Ritchie (1986) \\
\hline 50.3 & 323.3 & 0.00309 & 4.32 & 0.00554 & Ritchie (1986) \\
\hline 50.9 & 323.9 & 0.00309 & 4.47 & 0.00801 & Ritchie (1986) \\
\hline 59.9 & 332.9 & 0.00300 & 7.65 & 0.0133 & Ritchie (1986) \\
\hline 59.9 & 332.9 & 0.00300 & 12.61 & 0.0175 & Ritchie (1986) \\
\hline 60 & 333 & 0.00300 & 1.25 & 0.0103 & Ritchie (1986) \\
\hline 60 & 333 & 0.00300 & 3.19 & 0.00859 & Ritchie (1986) \\
\hline 60 & 333 & 0.00300 & 7.45 & 0.0105 & Ritchie (1986) \\
\hline 60 & 333 & 0.00300 & 9.64 & 0.0149 & Ritchie (1986) \\
\hline 60 & 333 & 0.00300 & 12.33 & 0.0331 & Ritchie (1986) \\
\hline
\end{tabular}


Table Al. Oxidation of Uranium in Oxygen Free Water Vapor. (Continued)

\begin{tabular}{|c|c|c|c|c|c|}
\hline \multicolumn{3}{|c|}{ Temperature } & \multirow{2}{*}{$\begin{array}{c}\text { Water Vapor } \\
\text { Pressure } \\
(\mathrm{kPa})\end{array}$} & \multirow{2}{*}{$\begin{array}{c}\text { Oxidation } \\
\text { Rate } \\
\left(\mathrm{mg} / \mathrm{cm}^{2}-\mathrm{h}\right)\end{array}$} & \multirow[b]{2}{*}{ Reference } \\
\hline$\left({ }^{\circ} \mathrm{C}\right)$ & (K) & $\left(K^{-1}\right)$ & & & \\
\hline 60.1 & 333.1 & 0.00300 & 2.40 & 0.00856 & Ritchie (1986) \\
\hline 60.5 & 333.5 & 0.00300 & 12.47 & 0.0276 & Ritchie (1986) \\
\hline 60.9 & 333.9 & 0.00299 & 4.24 & 0.0110 & Ritchie (1986) \\
\hline 61.9 & 334.9 & 0.00299 & 15.52 & 0.0215 & Ritchie (1986) \\
\hline 69.4 & 342.4 & 0.00292 & 12.02 & 0.0250 & Ritchie (1986) \\
\hline 70 & 343 & 0.00292 & 7.79 & 0.0242 & Ritchie (1986) \\
\hline 70 & 343 & 0.00292 & 12.34 & 0.0332 & Ritchie (1986) \\
\hline 70.1 & 343.1 & 0.00291 & 1.25 & 0.0125 & Ritchie (1986) \\
\hline 70.1 & 343.1 & 0.00291 & 2.35 & 0.0175 & Ritchie (1986) \\
\hline 70.1 & 343.1 & 0.00291 & 2.38 & 0.0168 & Ritchie (1986) \\
\hline 70.1 & 343.1 & 0.00291 & 2.50 & 0.0149 & Ritchie (1986) \\
\hline 70.1 & 343.1 & 0.00291 & 4.26 & 0.0164 & Ritchie (1986) \\
\hline 70.1 & 343.1 & 0.00291 & 4.32 & 0.0194 & Ritchie (1986) \\
\hline 70.1 & 343.1 & 0.00291 & 5.66 & 0.0208 & Ritchie (1986) \\
\hline 70.1 & 343.1 & 0.00291 & 5.76 & 0.0222 & Ritchie (1986) \\
\hline 70.1 & 343.1 & 0.00291 & 5.76 & 0.0290 & Ritchie (1986) \\
\hline 70.1 & 343.1 & 0.00291 & 7.45 & 0.0185 & Ritchie (1986) \\
\hline 70.1 & 343.1 & 0.00291 & 7.51 & 0.0263 & Ritchie (1986) \\
\hline 70.1 & 343.1 & 0.00291 & 7.51 & 0.0277 & Ritchie (1986) \\
\hline 70.1 & 343.1 & 0.00291 & 9.67 & 0.0305 & Ritchie (1986) \\
\hline 70.1 & 343.1 & 0.00291 & 9.79 & 0.0263 & Ritchie (1986) \\
\hline 70.1 & 343.1 & 0.00291 & 12.45 & 0.0471 & Ritchie (1986) \\
\hline 70.1 & 343.1 & 0.00291 & 12.52 & 0.0372 & Ritchie (1986) \\
\hline 70.1 & 343.1 & 0.00291 & 15.96 & 0.0332 & Ritchie (1986) \\
\hline 70.1 & 343.1 & 0.00291 & 19.93 & 0.0471 & Ritchie (1986) \\
\hline 70.1 & 343.1 & 0.00291 & 20.37 & 0.0389 & Ritchie (1986) \\
\hline 70.6 & 343.6 & 0.00291 & 20.45 & 0.0554 & Ritchie (1986) \\
\hline 70.9 & 343.9 & 0.00291 & 6.30 & 0.0175 & Ritchie (1986) \\
\hline
\end{tabular}


HNF-2853, Rev, 0

Table A1. 0xidation of Uranium in 0xygen Free Water Vapor. (Continued)

\begin{tabular}{|c|c|c|c|c|c|}
\hline \multicolumn{3}{|c|}{ Temperature } & \multirow{2}{*}{$\begin{array}{c}\text { Water Vapor } \\
\text { Pressure } \\
\text { (kPa) }\end{array}$} & \multirow{2}{*}{$\begin{array}{c}\text { Oxidation } \\
\text { Rate } \\
\left(\mathrm{mg} / \mathrm{cm}^{2}-\mathrm{h}\right)\end{array}$} & \multirow[b]{2}{*}{ Reference } \\
\hline$\left({ }^{\circ} \mathrm{C}\right)$ & (K) & $\left(K^{-1}\right)$ & & & \\
\hline 71.2 & 344.2 & 0.00291 & 12.76 & 0.0288 & Ritchie (1986) \\
\hline 71.4 & 344.4 & 0.00290 & 24.02 & 0.0375 & Ritchie (1986) \\
\hline 80 & 353 & 0.00283 & 4.26 & 0.0239 & Ritchie (1986) \\
\hline 80 & 353 & 0.00283 & 8.10 & 0.0376 & Ritchie (1986) \\
\hline 80 & 353 & 0.00283 & 12.36 & 0.0512 & Ritchie (1986) \\
\hline 80 & 353 & 0.00283 & 19.93 & 0.0566 & Ritchie (1986) \\
\hline 80 & 353 & 0.00283 & 19.93 & 0.0590 & Ritchie (1986) \\
\hline 80 & 353 & 0.00283 & 35.41 & 0.0699 & Ritchie (1986) \\
\hline 80.1 & 353.1 & 0.00283 & 20.10 & 0.0721 & Ritchie (1986) \\
\hline 80.2 & 353.2 & 0.00283 & 20.38 & 0.0514 & Ritchie (1986) \\
\hline 80.2 & 353.2 & 0.00283 & 31.83 & 0.1026 & Ritchie (1986) \\
\hline 80.3 & 353.3 & 0.00283 & 4.36 & 0.0324 & Ritchie (1986) \\
\hline 80.4 & 353.4 & 0.00283 & 1.25 & 0.0167 & Ritchie (1986) \\
\hline 80.4 & 353.4 & 0.00283 & 1.40 & 0.0211 & Ritchie (1986) \\
\hline 80.4 & 353.4 & 0.00283 & 2.50 & 0.0222 & Ritchie (1986) \\
\hline 80.5 & 353.5 & 0.00283 & 2.41 & 0.0263 & Ritchie (1986) \\
\hline 80.5 & 353.5 & 0.00283 & 4.24 & 0.0327 & Ritchie (1986) \\
\hline 80.5 & 353.5 & 0.00283 & 7.36 & 0.0374 & Ritchie (1986) \\
\hline 80.5 & 353.5 & 0.00283 & 12.56 & 0.0485 & Ritchie (1986) \\
\hline 80.5 & 353.5 & 0.00283 & 19.83 & 0.0737 & Ritchie (1986) \\
\hline 80.5 & 353.5 & 0.00283 & 31.38 & 0.0969 & Ritchie (1986) \\
\hline 80.6 & 353.6 & 0.00283 & 7.42 & 0.0394 & Ritchie (1986) \\
\hline 81.2 & 354.2 & 0.00282 & 12.27 & 0.0504 & Ritchie (1986) \\
\hline 81.4 & 354.4 & 0.00282 & 19.68 & 0.0655 & Ritchie (1986) \\
\hline 620 & 893 & 0.00112 & 101 & 56.2 & Scott (1959) \\
\hline 620 & 893 & 0.00112 & 101 & 93.4 & Scott (1959) \\
\hline 620 & 893 & 0.00112 & 101 & 102 & Scott (1959) \\
\hline 730 & 1003 & 0.00100 & 101 & 138 & Scott (1959) \\
\hline
\end{tabular}


HNF-2853, Rev. 0

Table Al. Oxidation of Uranium in 0xygen Free Water Vapor. (Continued)

\begin{tabular}{|c|c|c|c|c|c|}
\hline \multicolumn{3}{|c|}{ Temperature } & \multirow{2}{*}{$\begin{array}{c}\text { Water Vapor } \\
\text { Pressure } \\
(\mathrm{kPa})\end{array}$} & \multirow{2}{*}{$\begin{array}{c}\text { Oxidation } \\
\text { Rate } \\
\left(\mathrm{mg} / \mathrm{cm}^{2}-\mathrm{h}\right)\end{array}$} & \multirow[b]{2}{*}{ Reference } \\
\hline$\left({ }^{\circ} \mathrm{C}\right)$ & $(K)$ & $\left(K^{-1}\right)$ & & & \\
\hline 730 & 1003 & 0.00100 & 101 & 210 & Scott (1959) \\
\hline 730 & 1003 & 0.00100 & 101 & 211 & Scott (1959) \\
\hline 730 & 1003 & 0.00100 & 101 & 347 & Scott (1959) \\
\hline 780 & 1053 & 0.00095 & 101 & 236 & Scott (1959) \\
\hline 780 & 1053 & 0.00095 & 101 & 455 & $S \operatorname{cott}(1959)$ \\
\hline 990 & 1263 & 0.00079 & 101 & 271 & $S \operatorname{cott}(1959)$ \\
\hline 990 & 1263 & 0.00079 & 101 & 346 & Scott (1959) \\
\hline 990 & 1263 & 0.00079 & 101 & 465 & $S \operatorname{cott}(1959)$ \\
\hline 990 & 1263 & 0.00079 & 101 & 508 & $S \operatorname{cott}(1959)$ \\
\hline 1100 & 1373 & 0.00073 & 101 & 196 & $S \operatorname{cott}(1959)$ \\
\hline 1100 & 1373 & 0.00073 & 101 & 299 & Scott (1959) \\
\hline 1100 & 1373 & 0.00073 & 101 & 326 & Scott (1959) \\
\hline 1100 & 1373 & 0.00073 & 101 & 380 & $S \operatorname{cott}(1959)$ \\
\hline 1100 & 1373 & 0.00073 & 101 & 393 & Scott (1959) \\
\hline 1100 & 1373 & 0.00073 & 101 & 402 & $S \operatorname{cott}(1959)$ \\
\hline 1100 & 1373 & 0.00073 & 101 & 475 & Scott (1959) \\
\hline 1100 & 1373 & 0.00073 & 101 & 780 & Scott (1959) \\
\hline 1100 & 1373 & 0.00073 & 101 & 1068 & Scott (1959) \\
\hline 1215 & 1488 & 0.00067 & 101 & 463 & $S \operatorname{cott}(1959)$ \\
\hline 1215 & 1488 & 0.00067 & 101 & 480 & Scott (1959) \\
\hline 1215 & 1488 & 0.00067 & 101 & 556 & $S \operatorname{cott}(1959)$ \\
\hline 1215 & 1488 & 0.00067 & 101 & 780 & $S \operatorname{cott}(1959)$ \\
\hline 1215 & 1488 & 0.00067 & 101 & 833 & Scott (1959) \\
\hline 1215 & 1488 & 0.00067 & 101 & 929 & Scott (1959) \\
\hline 1215 & 1488 & 0.00067 & 101 & 1203 & Scott (1959) \\
\hline 1215 & 1488 & 0.00067 & 101 & 1214 & Scott (1959) \\
\hline 1215 & 1488 & 0.00067 & 101 & 1254 & Scott $(1959)$ \\
\hline 1215 & 1488 & 0.00067 & 101 & 1532 & Scott $(1959)$ \\
\hline
\end{tabular}


HNF-2853, Rev, 0

Table A1. Oxidation of Uranium in Oxygen Free Water Vapor. (Continued)

\begin{tabular}{|c|c|c|c|c|c|}
\hline \multicolumn{3}{|c|}{ Temperature } & \multirow{2}{*}{$\begin{array}{c}\text { Water Vapor } \\
\text { Pressure } \\
(\mathrm{kPa})\end{array}$} & \multirow{2}{*}{$\begin{array}{c}\text { Oxidation } \\
\text { Rate } \\
\left(\mathrm{mg} / \mathrm{cm}^{2}-\mathrm{h}\right)\end{array}$} & \multirow[b]{2}{*}{ Reference } \\
\hline$\left({ }^{\circ} \mathrm{C}\right)$ & $(K)$ & $\left(K^{-1}\right)$ & & & \\
\hline 1215 & 1488 & 0.00067 & 101 & 1604 & Scott (1959) \\
\hline 1215 & 1488 & 0.00067 & 101 & 2340 & Scott (1959) \\
\hline 1215 & 1488 & 0.00067 & 101 & 2412 & Scott (1959) \\
\hline 1215 & 1488 & 0.00067 & 101 & 4356 & Scott (1959) \\
\hline 1440 & 1713 & 0.00058 & 101 & 895 & Scott (1959) \\
\hline 1440 & 1713 & 0.00058 & 101 & 985 & Scott (1959) \\
\hline 1440 & 1713 & 0.00058 & 101 & 1179 & Scott (1959) \\
\hline 1440 & 1713 & 0.00058 & 101 & 1500 & $S \operatorname{cott}(1959)$ \\
\hline 1440 & 1713 & 0.00058 & 101 & 2183 & $S \operatorname{cott}(1959)$ \\
\hline 1440 & 1713 & 0.00058 & 101 & 2273 & Scott (1959) \\
\hline 225 & 498 & 0.00201 & 1377 & 491 & Troutner (1960) \\
\hline 300 & 573 & 0.00175 & 1377 & 1400 & Troutner $(1960)$ \\
\hline 300 & 573 & 0.00175 & 6884 & 2545 & Troutner (1960) \\
\hline 400 & 673 & 0.00149 & 1377 & 2727 & Troutner (1960) \\
\hline 400 & 673 & 0.00149 & 6884 & 4000 & Troutner (1960) \\
\hline 400 & 673 & 0.00149 & 13769 & 6000 & Troutner (1960) \\
\hline 500 & 773 & 0.00129 & 1377 & 2182 & Troutner (1960) \\
\hline 500 & 773 & 0.00129 & 6884 & 2909 & Troutner (1960) \\
\hline 500 & 773 & 0.00129 & 13769 & 4909 & Troutner (1960) \\
\hline 57 & 330 & 0.00303 & 1.73 & 0.00592 & Waber (1958) \\
\hline 75 & 348 & 0.00287 & 19.27 & 0.02017 & Waber (1958) \\
\hline 150 & 423 & 0.00236 & 101 & 2.16 & Wathen (1943) \\
\hline 200 & 473 & 0.00211 & 101 & 16.0 & Wathen (1943) \\
\hline 250 & 523 & 0.00191 & 101 & 161 & Wathen (1943) \\
\hline 300 & 573 & 0.00175 & 101 & 193 & Wathen (1943) \\
\hline 100 & 373 & 0.00268 & 0.27 & 0.022 & Weirick (1984) \\
\hline 100 & 373 & 0.00268 & 0.27 & 0.0225 & Weirick (1984) \\
\hline 100 & 373 & 0.00268 & 0.27 & 0.023 & Weirick (1984) \\
\hline
\end{tabular}


HNF-2853, Rev. 0

Table Al. Oxidation of Uranium in Oxygen Free Water Vapor. (Continued)

\begin{tabular}{|c|c|c|c|c|c|}
\hline \multicolumn{3}{|c|}{ Temperature } & \multirow{2}{*}{$\begin{array}{c}\text { Water Vapor } \\
\text { Pressure } \\
\text { (KPa) }\end{array}$} & \multirow{2}{*}{$\begin{array}{l}\text { 0xidation } \\
\text { Rate } \\
\left.\text { (mg/ } \mathrm{cm}^{2}-\mathrm{h}\right)\end{array}$} & \multirow[b]{2}{*}{ Reference } \\
\hline$\left({ }^{\circ} \mathrm{C}\right)$ & (K) & $\left(K^{-1}\right)$ & & & \\
\hline 100 & 373 & 0.00268 & 0.50 & 0.029 & Weirick (1984) \\
\hline 100 & 373 & 0.00268 & 0.67 & 0.034 & Weirick (1984) \\
\hline 100 & 373 & 0.00268 & 0.67 & 0.035 & Weirick (1984) \\
\hline 100 & 373 & 0.00268 & 0.67 & 0.042 & Weirick (1984) \\
\hline 100 & 373 & 0.00268 & 1.33 & 0.048 & Weirick (1984) \\
\hline 100 & 373 & 0.00268 & 1.33 & 0.050 & Weirick (1984) \\
\hline 100 & 373 & 0.00268 & 2.00 & 0.056 & Weirick (1984) \\
\hline
\end{tabular}


HNF-2853, Rev, 0

This page intentionally left blank. 
Table A2. Oxidation of Uranium in Liquid Water.

\begin{tabular}{|c|c|c|c|c|c|}
\hline \multicolumn{3}{|c|}{ Temperature } & \multicolumn{2}{|r|}{ Oxidation Rate } & \multirow[b]{2}{*}{ Reference } \\
\hline (C) & $(K)$ & $\left(K^{-1}\right)$ & $\mathrm{mg} / \mathrm{cm}^{2}-\mathrm{h}$ & Comment & \\
\hline 35 & 308 & $3.25 \mathrm{e}-03$ & $7.68 \mathrm{e}-03$ & Degassed water (4) & Baker et al. (1966) \\
\hline 50 & 323 & $3.10 \mathrm{e}-03$ & $2.55 \mathrm{e}-02$ & Degassed water (4) & Baker et al. (1966) \\
\hline 65 & 338 & $2.96 \mathrm{e}-03$ & $8.95 \mathrm{e}-02$ & Degassed water $(4)$ & Baker et al. (1966) \\
\hline 80 & 353 & $2.83 e-03$ & $2.19 \mathrm{e}-01$ & Degassed water (4) & Baker et al. (1966) \\
\hline 100 & 373 & $2.68 \mathrm{e}-03$ & $4.91 \mathrm{e}-01$ & Degassed water (4) & Baker et al. (1966) \\
\hline 100 & 373 & $2.68 \mathrm{e}-03$ & $5.38 \mathrm{e}-01$ & Degassed water (4) & Baker et al. (1966) \\
\hline 100 & 373 & $2.68 \mathrm{e}-03$ & $5.65 \mathrm{e}-01$ & Degassed water (4) & Baker et al. (1966) \\
\hline 100 & 373 & $2.68 \mathrm{e}-03$ & $5.71 \mathrm{e}-01$ & Degassed water (4) & Baker et al. (1966) \\
\hline 100 & 373 & $2.68 \mathrm{e}-03$ & $5.58 \mathrm{e}-01$ & Degassed water (4) & Baker et al. (1966) \\
\hline 100 & 373 & $2.68 \mathrm{e}-03$ & $5.85 e-01$ & Degassed water (4) & Baker et al. (1966) \\
\hline 100 & 373 & $2.68 \mathrm{e}-03$ & $5.65 e-01$ & Degassed water (4) & Baker et a1. (1966) \\
\hline 183 & 456 & $2.19 \mathrm{e}-03$ & $1.87 e+01$ & Hydrogen saturated water(4) & Bensen et al. $(1945)^{*}$ \\
\hline 226 & 499 & $2.00 \mathrm{e}-03$ & $9.55 \mathrm{e}+01$ & Hydrogen saturated water (4) & Bensen et al. $(1945)^{*}$ \\
\hline 100 & 373 & $2.68 \mathrm{e}-03$ & $1.21 \mathrm{e}-01$ & Hydrogen saturated water(4) & Colbeck et a1. (1945)* \\
\hline 50 & 323 & $3.10 \mathrm{e}-03$ & $2.42 \mathrm{e}-04$ & Air saturated water (4) & Draley and English $(1945) * *$ \\
\hline 60 & 333 & $3.00 \mathrm{e}-03$ & $9.55 \mathrm{e}-04$ & Air saturated water ( 4 ) & Draley and English $(1945) * \star$ \\
\hline 70 & 343 & $2.92 \mathrm{e}-03$ & $1.83 \mathrm{e}-03$ & Air saturated water $(4)$ & Draley and English $(1945) * *$ \\
\hline 80 & 353 & $2.83 e-03$ & $7.73 \mathrm{e}-02$ & Air saturated water (4) & Draley and English $(1945)^{* *}$ \\
\hline 90 & 363 & $2.75 \mathrm{e}-03$ & $6.74 \mathrm{e}-02$ & Air saturated water (4) & Draley and English $(1945)^{* *}$ \\
\hline 50 & 323 & $3.10 \mathrm{e}-03$ & $8.90 \mathrm{e}-03$ & Hydrogen saturated water (4) & Draley and English $(1945)^{* *}$ \\
\hline 70 & 343 & $2.92 \mathrm{e}-03$ & $6.23 \mathrm{e}-02$ & Hydrogen saturated water (4) & Draley and English $(1945)^{\star *}$ \\
\hline 90 & 363 & $2.75 e-03$ & $1.36 \mathrm{e}-01$ & Hydrogen saturated water (4) & Draley and English $(1945)^{* *}$ \\
\hline 100 & 373 & $2.68 \mathrm{e}-03$ & $1.05 \mathrm{e}-01$ & Distilled water $(4,6)$ & Greninger et a1. (1945)* \\
\hline 100 & 373 & $2.68 \mathrm{e}-03$ & $1.56 \mathrm{e}-01$ & Distilled water $(4,6)$ & Greninger et a1. $(1945)^{*}$ \\
\hline 100 & 373 & $2.68 e-03$ & $1.04 \mathrm{e}-01$ & Distilled water $(4,6)$ & Greninger et a1. (1945)* \\
\hline 70 & 343 & $2.92 e-03$ & $2.82 \mathrm{e}-02$ & Helium sat. water (4) & Mollison et al. (1945)* \\
\hline 50 & 323 & $3.10 \mathrm{e}-03$ & $8.34 \mathrm{e}-03$ & Hydrogen saturated water(4) & Mollison et al. (1945)* \\
\hline
\end{tabular}


Table A2. Oxidation of Uranium in Liquid Water. (Continued)

\begin{tabular}{|c|c|c|c|c|c|}
\hline \multicolumn{3}{|c|}{ Temperature } & \multicolumn{2}{|r|}{ Oxidation Rate } & \multirow[b]{2}{*}{ Reference } \\
\hline (C) & $(K)$ & $\left(K^{-1}\right)$ & $\mathrm{mg} / \mathrm{cm}^{2}-\mathrm{h}$ & Comment & \\
\hline 70 & 343 & $2.92 \mathrm{e}-03$ & $4.71 \mathrm{e}-02$ & Hydrogen saturated water $(4)$ & Mollison et a1.(1945)* \\
\hline 90 & 363 & $2.75 \mathrm{e}-03$ & $1.61 \mathrm{e}-01$ & Hydrogen saturated water (4) & Mollison et al. (1945)* \\
\hline 100 & 373 & $2.68 \mathrm{e}-03$ & $3.63 \mathrm{e}-01$ & Hydrogen saturated water(4) & Mollison et al. (1945)* \\
\hline 70 & 343 & $2.92 \mathrm{e}-03$ & $3.36 \mathrm{e}-02$ & Nitrogen sat. water (4) & Mollison et al.(1945)* \\
\hline 100 & 373 & $2.68 \mathrm{e}-03$ & $3.63 e-01$ & Distilled water $(4,5)$ & Mollison et a1.(1945)* \\
\hline 100 & 373 & $2.68 \mathrm{e}-03$ & $1.48 \mathrm{e}-01$ & Distilled water $(4,6)$ & Mollison et al. (1945)* \\
\hline 100 & 373 & $2.68 \mathrm{e}-03$ & $2.08 \mathrm{e}-01$ & Distilled water $(4,6)$ & Mollison et a1.(1945)* \\
\hline 100 & 373 & $2.68 \mathrm{e}-03$ & $2.74 \mathrm{e}-01$ & Distilled water $(4,6)$ & Mollison et al. (1945)* \\
\hline 100 & 373 & $2.68 \mathrm{e}-03$ & $2.42 \mathrm{e}-01$ & Distilled water $(4,6)$ & Mollison et a1.(1945)* \\
\hline 100 & 373 & $2.68 \mathrm{e}-03$ & $2.92 \mathrm{e}-01$ & Distilled water $(4,6)$ & Mollison et a1.(1945)* \\
\hline 100 & 373 & $2.68 \mathrm{e}-03$ & $1.57 \mathrm{e}-01$ & Distilled water $(4,6)$ & Mollison et al.(1945)* \\
\hline 100 & 373 & $2.68 \mathrm{e}-03$ & $1.26 \mathrm{e}-01$ & Distilled water $(4,6)$ & Mollison et al. (1945)* \\
\hline 100 & 373 & $2.68 \mathrm{e}-03$ & $1.48 \mathrm{e}-01$ & Distilled water $(4,6)$ & Mollison et a1.(1945)* \\
\hline 100 & 373 & $2.68 \mathrm{e}-03$ & $2.26 \mathrm{e}-01$ & Distilled water $(4,6)$ & Mollison et a1. (1945)* \\
\hline 100 & 373 & $2.68 \mathrm{e}-03$ & $2.86 \mathrm{e}-01$ & Distilled water $(4,6)$ & Mollison et al. $(1945)^{*}$ \\
\hline 100 & 373 & $2.68 \mathrm{e}-03$ & $8.87 e-02$ & Distilled water $(4,6)$ & Mollison et al. $(1945)^{*}$ \\
\hline 100 & 373 & $2.68 \mathrm{e}-03$ & $3.28 e-01$ & Distilled water $(4,6)$ & Mollison et al. (1945)* \\
\hline 35 & 308 & $3.25 \mathrm{e}-03$ & $9.55 \mathrm{e}-03$ & Gas-free water (4) & Orman (1963) \\
\hline 65 & 338 & $2.96 \mathrm{e}-03$ & $8.47 \mathrm{e}-02$ & Gas-free water (4) & Orman (1963) \\
\hline 80 & 353 & $2.83 e-03$ & $2.35 \mathrm{e}-01$ & Gas-free water (4) & Orman (1963) \\
\hline 21 & 294 & $3.40 \mathrm{e}-03$ & $8.00 e-03$ & $K$ West Basin water $* * *$ & Pajunen (1998) \\
\hline 21 & 294 & $3.40 \mathrm{e}-03$ & $1.20 \mathrm{e}-03$ & $K$ West Basin water $* * *$ & Pajunen (1998) \\
\hline 21 & 294 & $3.40 \mathrm{e}-03$ & $1.00 \mathrm{e}-03$ & $K$ West Basin water*** & Pajunen (1998) \\
\hline 21 & 294 & $3.40 \mathrm{e}-03$ & $1.30 \mathrm{e}-02$ & $K$ West Basin water $* \star \star *$ & Pajunen(1998) \\
\hline 100 & 373 & $2.68 \mathrm{e}-03$ & $3.94 \mathrm{e}-01$ & Boiled, deionized water(4) & Schroeder (1959) \\
\hline 100 & 373 & $2.68 \mathrm{e}-03$ & $4.09 \mathrm{e}-01$ & Boiled, deionized water(4) & Schroeder (1959) \\
\hline 100 & 373 & $2.68 e-03$ & $4.38 \mathrm{e}-01$ & Boiled, deionized water(4) & Schroeder(1959) \\
\hline
\end{tabular}


Table A2. Oxidation of Uranium in Liquid Water. (Continued)

\begin{tabular}{|c|c|c|c|c|c|}
\hline \multicolumn{3}{|c|}{ Temperature } & \multicolumn{2}{|r|}{ Oxidation Rate } & \multirow[b]{2}{*}{ Reference } \\
\hline (C) & $(K)$ & $\left(K^{-1}\right)$ & $\mathrm{mg} / \mathrm{cm}^{2}-\mathrm{h}$ & Comment & \\
\hline 100 & 373 & $2.68 \mathrm{e}-03$ & $3.74 \mathrm{e}-01$ & Boiled, deionized water(4) & Schroeder (1959) \\
\hline 100 & 373 & $2.68 \mathrm{e}-03$ & $4.41 \mathrm{e}-01$ & Boiled, deionized water (4) & Schroeder (1959) \\
\hline 200 & 473 & $2.11 \mathrm{e}-03$ & $3.54 \mathrm{e}+01$ & Surface penetration data & Troutner (1960) \\
\hline 200 & 473 & $2.11 \mathrm{e}-03$ & $4.28 e+01$ & Surface penetration data & Troutner (1960) \\
\hline 200 & 473 & $2.11 \mathrm{e}-03$ & $3.85 e+01$ & Surface penetration data & Troutner (1960) \\
\hline 225 & 498 & $2.01 \mathrm{e}-03$ & $1.01 \mathrm{e}+02$ & Surface penetration data & Troutner (1960) \\
\hline 225 & 498 & $2.01 \mathrm{e}-03$ & $1.17 \mathrm{e}+02$ & Surface penetration data & Troutner $(1960)$ \\
\hline 250 & 523 & $1.91 \mathrm{e}-03$ & $2.49 \mathrm{e}+02$ & Surface penetration data & Troutner $(1960)$ \\
\hline 250 & 523 & $1.91 \mathrm{e}-03$ & $2.37 e+02$ & Surface penetration data & Troutner (1960) \\
\hline 250 & 523 & $1.91 \mathrm{e}-03$ & $2.22 \mathrm{e}+02$ & Surface penetration data & Troutner (1960) \\
\hline 300 & 573 & $1.75 \mathrm{e}-03$ & $7.24 \mathrm{e}+02$ & Surface penetration data & Troutner (1960) \\
\hline 300 & 573 & $1.75 \mathrm{e}-03$ & $6.19 \mathrm{e}+02$ & Surface penetration data & Troutner $(1960)$ \\
\hline 50 & 323 & $3.10 \mathrm{e}-03$ & $1.32 \mathrm{e}-06$ & Purified water $* \star *$ & Waber (1958) \\
\hline 50 & 323 & $3.10 \mathrm{e}-03$ & $5.19 \mathrm{e}-06$ & Purified water & Waber (1958) \\
\hline 50 & 323 & $3.10 \mathrm{e}-03$ & $8.62 \mathrm{e}-06$ & Purified water & Waber (1958) \\
\hline 50 & 323 & $3.10 \mathrm{e}-03$ & $1.64 \mathrm{e}-05$ & Purified water & Waber (1958) \\
\hline 50 & 323 & $3.10 \mathrm{e}-03$ & $2.17 \mathrm{e}-05$ & Purified water & Waber (1958) \\
\hline 50 & 323 & $3.10 \mathrm{e}-03$ & $3.43 \mathrm{e}-05$ & Purified water & Waber (1958) \\
\hline 50 & 323 & $3.10 \mathrm{e}-03$ & $4.91 \mathrm{e}-05$ & Purified water & Waber (1958) \\
\hline 50 & 323 & $3.10 \mathrm{e}-03$ & $5.79 e-05$ & Purified water & Waber (1958) \\
\hline 50 & 323 & $3.10 \mathrm{e}-03$ & $7.75 e-05$ & Purified water*** & Waber (1958) \\
\hline
\end{tabular}

*As reported by McWhirter and Draley (1952).

$* *$ As reported by Waber (1952).

***Hydrogen generation data.

(4) Weight loss data.

(5)As-cast uranium.

(6) Heat treated uranium. 


\begin{tabular}{|c|c|c|c|c|c|}
\hline \multicolumn{6}{|c|}{ DISTRIBUTION SHEET } \\
\hline \multirow{2}{*}{$\begin{array}{l}\text { To } \\
\text { Distribution }\end{array}$} & \multirow{2}{*}{\multicolumn{3}{|c|}{$\begin{array}{l}\text { From } \\
\text { SNF Characterization Project }\end{array}$}} & \multicolumn{2}{|l|}{ Page 1 of 2} \\
\hline & & & & \multicolumn{2}{|c|}{ Date November 1998} \\
\hline \multicolumn{4}{|l|}{ Project Title/Work Order } & \multicolumn{2}{|c|}{ EDT No. 620819} \\
\hline \multicolumn{4}{|c|}{$\begin{array}{l}\text { Reaction Rate Constant for Uranium in Water and Water Vapor } \\
\text { HNF-2853, Rev. } 0\end{array}$} & \multicolumn{2}{|l|}{ ECN No. } \\
\hline Name & MSIN & $\begin{array}{l}\text { Text } \\
\text { With All } \\
\text { Attach. }\end{array}$ & Text Only & $\begin{array}{c}\text { Attach./ } \\
\text { Appendix } \\
\text { Only }\end{array}$ & $\begin{array}{l}\text { EDT/ECN } \\
\text { Only }\end{array}$ \\
\hline
\end{tabular}

Fluor Daniel Hanford, Inc.
R. L. McCormack
R3-11
$X$

ARES

R. D. Crowe

R3-26

$X$

B\&W Hanford Company
T. D. Cooper
T5-12
$X$

B\&W Protec, Inc.

T. L. Welsh

T4-40 X

\section{COGEMA}
A. L. Pajunen
R3-86
$X$

Duke Engineering \& Services Hanford, Inc.
R. B. Baker
D. W. Bergmann
L. D. Bruggeman
D. R. Duncan
J. R. Frederickson
L. H. Goldman
S. L. Hecht
L. A. Lawrence
B. J. Makenas
R. P. Omberg
A. L. Pitner
A. M. Segrest
J. A. Swenson
D. J. Trimble
J. H. Wicks
SNF Project Files

$\begin{array}{ll}H 0-40 & X \\ H 0-40 & X \\ H 0-40 & X \\ \text { R3-86 } & X \\ \text { R3-86 } & X \\ \text { R3-86 } & X \\ H 0-40 & X \\ H O-40 & X \\ H 0-40 & X \\ H 0-40 & X \\ H 0-40 & X \\ \text { R3-11 } & X \\ \text { R3-11 } & X \\ \text { H0-40 } & X \\ X 3-74 & X \\ \text { R3-11 } & X\end{array}$

\section{Fauske \& Associates}

M. G. Plys

S7-14 X 


\section{DISTRIBUTION SHEET}

\begin{tabular}{|c|c|c|c|c|c|}
\hline \multirow{2}{*}{$\begin{array}{l}\text { To } \\
\text { Distribution }\end{array}$} & \multirow{2}{*}{\multicolumn{3}{|c|}{$\begin{array}{l}\text { From } \\
\text { SNF Characterization Project }\end{array}$}} & \multicolumn{2}{|l|}{ Page 2 of 2} \\
\hline & & & & \multicolumn{2}{|c|}{ Date November 1998} \\
\hline \multicolumn{4}{|l|}{ Project Title/Work Order } & \multicolumn{2}{|c|}{ EDT No. 620819} \\
\hline \multicolumn{4}{|c|}{$\begin{array}{l}\text { Reaction Rate Constant for Uranium in Water and Water Vapor } \\
\text { HNF-2853, Rev. } 0\end{array}$} & \multicolumn{2}{|l|}{ ECN No. } \\
\hline Name & MSIN & $\begin{array}{c}\text { Text } \\
\text { With All } \\
\text { Attach. }\end{array}$ & Text Only & $\begin{array}{l}\text { Attach./ } \\
\text { Appendix } \\
\text { Only }\end{array}$ & $\begin{array}{l}\text { EDT/ECN } \\
\text { Only }\end{array}$ \\
\hline
\end{tabular}

Lockheed Martin Services, Inc.

Central Files

DPC

Numatec Hanford Corporation

T. A. Flament

C. R. Miska

J. P. Sloughter

Pacific Northwest National Laboratory

J. Abrefah

S. C. Marschman

TRI

D. E. Ball

U.S. Department of Energy

Richland Operations office

P. G. Loscoe

J. Shuen

$\begin{array}{ll}\text { A3-88 } & X \\ \text { A3-89 } & X\end{array}$

H5-25

R3-86

H5- 49

$x$

$x$

$x$

P7-27 $X$.

P7-27 $X$

R3-86 X

S7-41 $\quad x$ 